\title{
Working
}

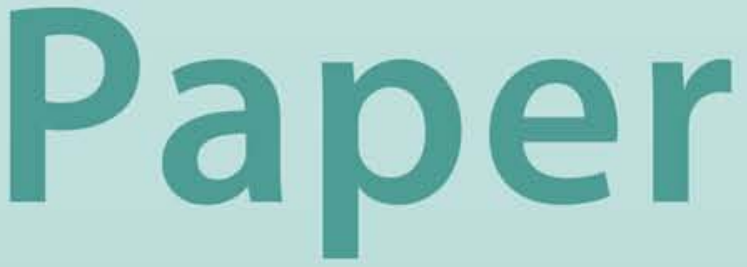


Explaining Expisodes of Growth Accelerations, Decelerations, and Collapses in Western Africa

Patrick Imam and Gonzalo Salinas 
(C) 2008 International Monetary Fund

$\mathrm{WP} / 08 / 287$

\title{
IMF Working Paper
}

African Department

\section{Explaining Episodes of Growth Accelerations, Decelerations, and Collapses in Western Africa}

\section{Prepared by Patrick Imam and Gonzalo Salinas ${ }^{1}$}

\author{
Authorized for distribution by Emilio Sacerdoti
}

December 2008

\section{This Working Paper should not be reported as representing the views of the IMF.}

The views expressed in this Working Paper are those of the authors and do not necessarily represent those of the IMF or IMF policy. Working Papers describe research in progress by the authors and are published to elicit comments and to further debate.

\begin{abstract}
The growth literature has had problems explaining the "sub-Saharan African growth dummy" in cross-country regressions. Instead of taking the usual approach of focusing on long-run growth and assuming that sub-Saharan countries have homogenous parameters in growth regressions, we concentrate our analysis on episodes of growth turnarounds (identifying growth accelerations, decelerations, and collapses) and use only West African countries in our sample. The driving force of growth turnarounds are estimated by analyzing external shocks, political and institutional changes, economic reforms, and indicators particularly relevant to the region. Using probits for a group of 22 Western African economies for the period 1960-2006, we find that growth accelerations are most clearly associated with external shocks, economic liberalization, political stability, and closeness to the coast; decelerations occurred during short-lived regimes and when corruption indices weakened; and collapses are linked to external shocks, falling domestic credit, and proximity to the coast. We then identify policy implications.

JEL Classification Numbers: O11, O40, N17

Keywords: Growth, Acceleration, Deceleration, Africa

Author's E-Mail Address:pimam@imf.org; gsalinas@imf.org

\footnotetext{
${ }^{1}$ We would like to thank Andy Berg, Philippe Callier, Hamid Davoodi, Arend Kouwenaar, Camelia Minoiu, Mahvash Quershi, Emilio Sacerdoti, Issouf Samake, Janet Stotsky and participants in the African Growth seminar for helpful comments. The usual disclaimer applies.
} 


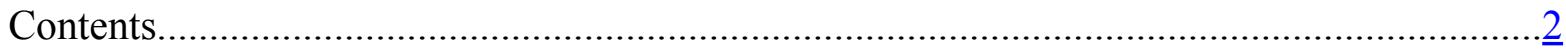

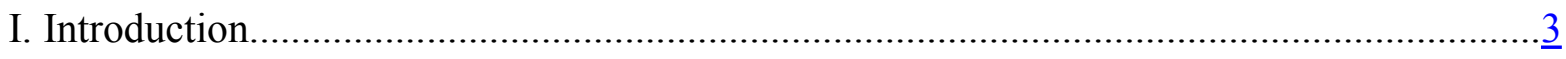

II. West African Economic Performance in Perspective ...............................................................

III. Growth Turnarounds and Their Determinants ...........................................................11

A. Identifying Growth Turnarounds .....................................................................11

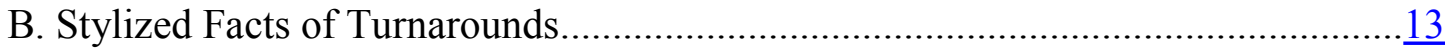

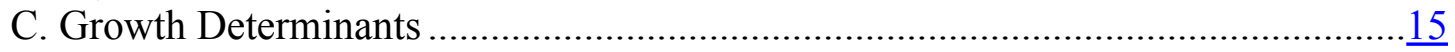

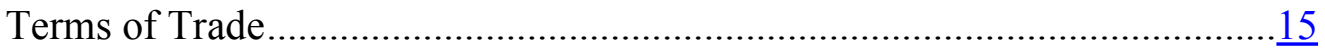

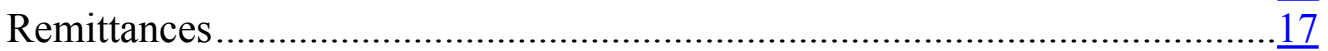

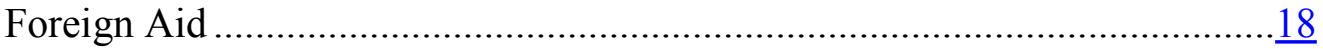

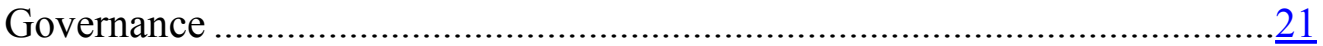

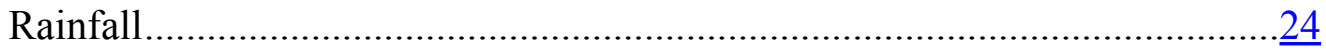

Ethnic Fractionalization ........................................................................

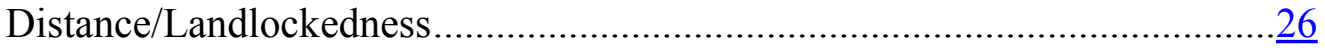

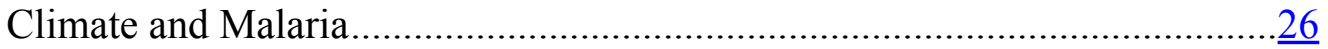

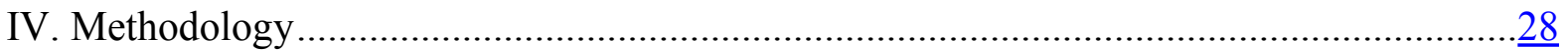

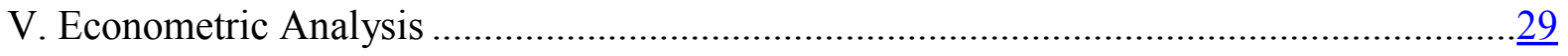

VI. Conclusion And Policy Implications ........................................................................... 


\section{INTRODUCTION}

While conditions at independence in the 1950s and 1960s were not highly auspicious for most countries in sub-Saharan Africa (SSA), few economists predicted the substantial decline in per capita income these countries suffered in subsequent decades. In fact, leading academics like Mydral (1968) had more confidence in Africa's development than in East Asia's at the time. Why has SSA's growth, particularly in West Africa, been disappointing?

Ever since the seminal paper by Barro (1991), there has been a quest to explain growth, or lack thereof, in SSA. SSA's growth has been unique in its high volatility, unevenness across countries and over time, and tendencies to retrogress. Barro, using a crosssection of 98 countries for 1960-85, found that after taking account of conventional growth determinants, the dummy variable for SSA was negative and statistically significant; this suggests there was something unique explaining the African growth process. Doppelhofer, Miller, and Salai-i-Martin (2004), using Bayesian averaging, confirmed Barro's finding. They concluded that African growth was on average 1.28 percent a year lower than what would be predicted given Africa's other characteristics, such as high fertility, low investment rates, low education levels, and ethnicity.

In fact, most empirical studies find that much of SSA's slow and variable growth pattern cannot be explained by the usual variables. It is noteworthy that the economic profession views SSA as not growing differently than other regions; they believe that only a high-risk environment (e.g. terms of trade volatility) combined with weak institutions constrains the action of otherwise rational economic agents (Collier and Gunning, 1999). Those studies that concluded that the SSA dummy is insignificant after adjusting for factors such as geography, neighborhood effect, tropical diseases, etc., have often been refuted for lack of robustness (see Collier and Gunning, 1999 for a summary). In our opinion the literature has not been able to identify the cause of Barro's enigma in part because most studies suffer from at least four major flaws.

First, studies using Barro-type growth regressions (regressing income growth on such macroeconomic variables as capital investments and labor growth) often include right handside variables that are endogenous to growth (such as institutions or fertility), making it difficult to draw solid conclusions about causality. Moreover, when instrumental variables are used to solve the problem, they themselves are often highly endogenous, making the exercise somewhat futile. For example, in a much celebrated work, Acemoglu, Johnson, and Robinson (2001) argued that mortality risk or indigenous population density shaped European settlement decisions. They argue, therefore, that where European settlements arose, their institutions supplanted indigenous ones. However, it seems unlikely that Europeans brought with them only their institutions. More likely, they also brought their human capital and technologies (see, for instance, Djankov et al., 2003). In econometric terms, valid instruments must be uncorrelated with the error term: if settlement patterns influence growth through channels other than institutions, the instruments are not valid. Because most instrumental variables used in the growth literature suffer from this defect, the endogeneity problem persists. 
While the endogeneity problem cannot be fully addressed in a macroeconometric study because instrumental variables are limited, we believe the growth turnarounds we identify are more likely to be determined by exogenous factors. Therefore, focusing on shortrun growth episodes in Western Africa and analyzing mainly time-variant factors should help in formulating advice on what policymakers should attempt to do and what should be avoided. We attempt to identify growth turnaround periods as follows: when growth accelerated; when it decelerated; and when decelerations lead to negative growth. The last type allows us to focus on the drastic episodes that are particularly frequent in the region and that may have different causes than less detrimental growth decelerations.

Second, most of these studies deal with cross-section econometrics, regressing average growth rates for several years on (often invariant) country characteristics and policies. As Easterly et al. (1993) discovered more than a decade ago, long-run growth is rather unstable - only the East Asian tiger economies have been able to sustain growth over several decades. Most countries in SSA have seen cycles of growth, with rising growth followed by stagnation or decline. Attempting to explain long-run average growth on a series that is highly cyclical and unstable (see, for example, Chart 1), using regression techniques based on ordinary least squares, is inappropriate, because the results will be driven largely by the outliers. ${ }^{2}$

Chart 1: Ordinary Least Squares (OLS) for a Country with Highly Volatile Growth

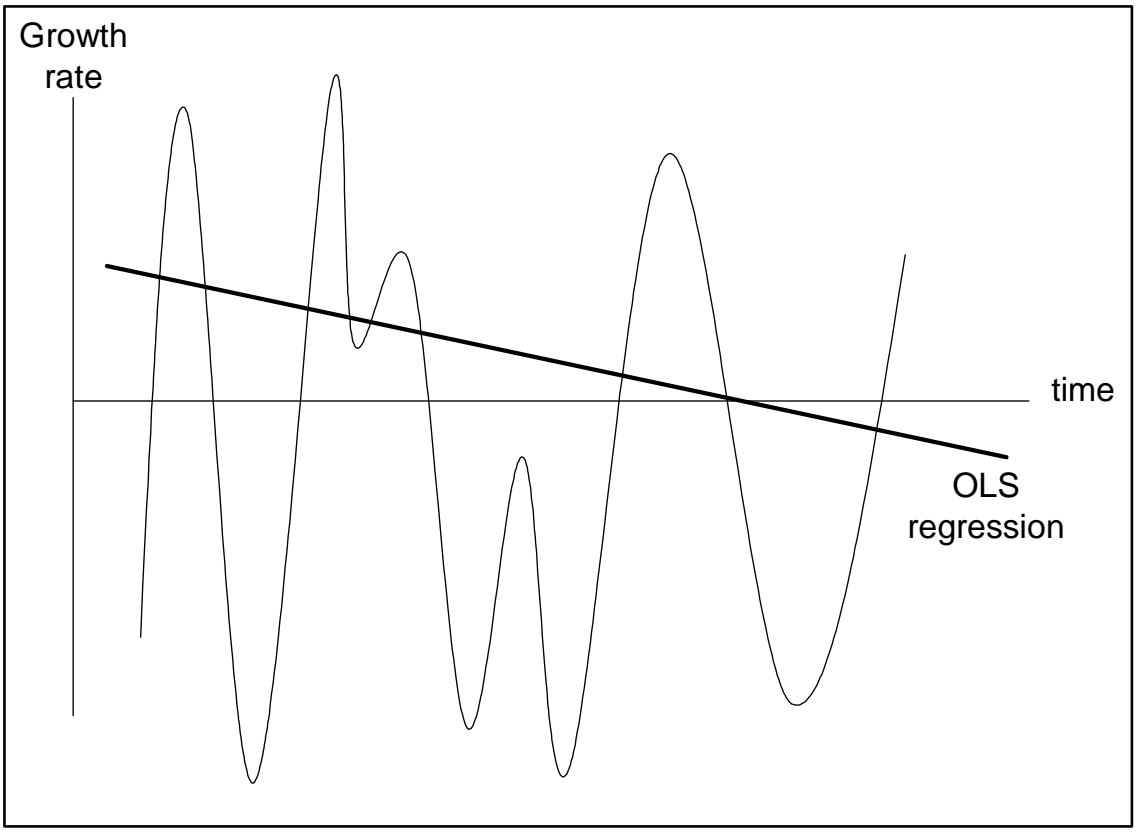

\footnotetext{
${ }^{2}$ Country outliers have often been found to drive some results of studies that include SSA countries. De Long and Summers (1991) in their study of the impact of equipment investment on growth found that Botswana, the fastest-growing economy, and Zambia, the slowest-growing, exerted substantial influence on their cross-section findings. Similarly, the study by Burnside and Dollar (2000) on the impact of aid on growth was criticized for lack of robustness once outlying countries such as Botswana are taken into account (see Easterly, 2003).
} 
A more appropriate question to ask of high-volatility data is what explains the shortrun volatilities of accelerating and decelerating growth episodes. In Africa, the fact that growth has normally been highly volatile should act as a warning against any attempt to analyze long-run average growth. An alternative approach is to look only at particular periods, such as around significant growth turnarounds, that could convey probably more valuable information (see also Hausmann, Pritchett, and Rodrik, 2006). ${ }^{3}$ To our knowledge, no short-run analysis of growth episodes specifically in Western African countries has yet been done.

Third, Barro-type regressions that attempt to explain the SSA dummy include mostly time-invariant variables (e.g., geography, ethnicity). While appropriate in explaining level effects, on their own they cannot explain changes in growth over time. For example, tropical diseases can explain differences in income levels between SSA and other regions, it is unlikely that on their own they can explain variations in income growth over time. Changes in year-to-year growth are likely to be spurred by time-variant factors, such as policy variables or external factors like terms of trade shocks. We will therefore largely use timevariant factors as dependent variables in our analysis.

Finally, previous studies mask the fact that SSA growth is heterogeneous. Some countries and regions have seen a consistent rise in income, others stagnation, and others continued declines. Previous studies that attempt to explain the SSA dummy implicitly assume that Africa's growth is a function of different mean levels for given independent variables, i.e., they force equality between SSA and non-SSA slope coefficients, implying that the marginal impacts of explanatory variables are the same in SSA as elsewhere. Studies that pool all of SSA together hide much of the heterogeneity in time and across countries within SSA. That is why we limit our sample to countries in Western Africa, a region that has similar structural commonalities.

Western Africa ${ }^{4}$ is a poor region on the poorest continent. For the past five decades, its average per capita income has stagnated. But the outcome has not been uniform. Some countries, like Burkina Faso, have grown steadily, though slowly, since independence. Others, like Cote d'Ivoire, after a successful start, have regressed to where they were at independence. Niger, where per capita income has steadily declined to half the level it was at independence, is the extreme case of what has too often been the norm in Western Africa

\footnotetext{
${ }^{3}$ Similarly, exploring the determinants of short-run growth, in particular phases of acceleration and deceleration, can be more informative than Barro-type regressions, which do not produce firm policy conclusions that policymakers can implement in the short run. Finding for example that investment in human capital is good for growth in the long-run might have limited policy implications for governments that understand that are interest in reforms that bear fruits in the short-run. Focusing on short-run dynamics that use policy variables as explanations, as Hausmann, Pritchett, and Rodrik (2006) did, has the advantage of offering policymakers advice they can apply that in fact has short-run benefits.

${ }^{4}$ In this paper we define the West African region as comprising Benin, Burkina Faso, Cameroon, Cape Verde, Chad, Central African Republic, Republic of Congo, Côte d'Ivoire, Gabon, Guinea, Equatorial Guinea, São Tomé and Príncipe, Niger, Nigeria, Mali, Mauritania, Togo, Ghana, Liberia, Sierra Leone, Senegal, and the Gambia.
} 
(see Figure 1). Because this variation in experience will provide us with a great deal of information in our regression analysis, it could help us extract important policy implications.

Figure 1: Examples of Rising, Stagnating, and Declining Income Per Capita Levels $(1960=100)$

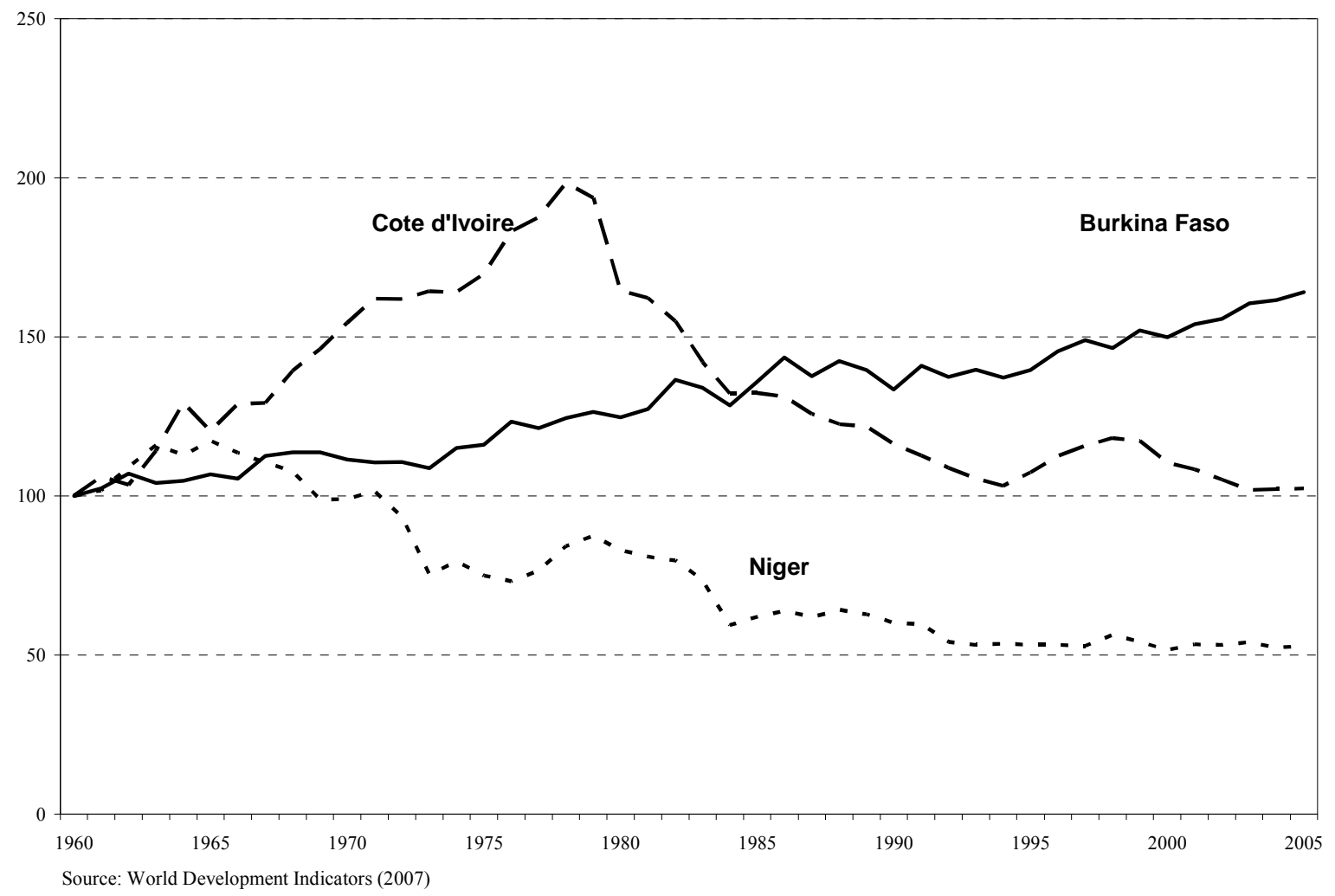

In this paper we aim to address the flaws we identified. Section II briefly reviews West Africa's economic growth record. In Section III we present our methodology for identifying acceleration, deceleration, and negative growth episodes. In Section IV, we categorize our data into external shock, political and institutional changes, economic reforms, and other variables specific to sub-Saharan Africa. We then carry out probit regressions and discuss our findings in Section V. Section VI concludes.

\section{The Performance of West African Economies in Perspective}

Much has been written already about African growth performance, and we will therefore only briefly review the growth process of Western African countries (see, e.g., Johnson, Ostry, and Subramanian, 2007, and Ndulu et al., 2000). One interesting observations from recent studies is that it is not the case that African countries were never able to grow. Indeed, there are many episodes of short-run growth, even if they were usually followed by large episodes of negative growth. Pritchett (1998) illustrates that between 1973 and 1980 there was a single major break in the growth trends in most African economies, followed by a long stagnation lasting into the early 1990s. This is the period of the oil shocks 
and the debt crisis. Many countries have since recovered. In the long run, however, most countries in the region have hardly seen a rise in output growth, and SSA's per capita income has continuously fallen behind that of other regions.

Long-run stagnation and economic volatility are particularly characteristic of West African economies, although there has been wide variation across countries. For instance, Table 1 shows vastly different growth rates if we divide our sample into three groups: WAEMU, CEMAC, and others. ${ }^{5}$ CEMAC countries, almost all oil producers, have on average done well, particularly in the 1970s with the positive oil shocks, and in the 2000s as oil prices again increased. WAEMU countries as net oil importers have on the other hand suffered significantly for two decades, during the oil shock in the 1970s and the subsequent debt shock (and because of the overvaluation of their real effective exchange rates in the early 1990s). The others, mainly Anglophone countries, are mainly oil-importers, though some are large oil exporters (e.g. Nigeria); their growth pattern is more similar to that of the WAEMU countries - they suffered during 1980-2000 but have been growing fast ever since.

Table 1: Real GDP per Capita Growth Rates in Western Africa (1960-2005)

\begin{tabular}{lrrrrr}
\hline & $1961-69$ & $1970-79$ & $1980-89$ & $1990-99$ & $2000-05$ \\
\hline WAEMU & 1.918 & 0.584 & -1.258 & -1.136 & 0.237 \\
CEMAC & 1.155 & 2.095 & 0.907 & 1.811 & 2.591 \\
Other & 1.951 & 0.987 & -0.889 & 0.033 & 2.201 \\
\hline
\end{tabular}

Source: IMF World Economic Outlook

Since 2000 growth has been systematically high across the Western African region as a whole (see Figures 2A, 2B, and 2C) because of both improving terms of trade and better macroeconomic policies. Macroeconomic indicators like higher growth rates, lower inflation, and higher openness reflect not just a favorable exogenous environment but also domestic economic reforms and a more auspicious, less conflict-ridden, political environment.

\footnotetext{
${ }^{5}$ The WAEMU countries are Benin, Burkina Faso, Côte d'Ivoire, Guinea-Bissau, Mali, Niger, Senegal, and Togo. The CEMAC countries are Cameroon, the Central African Republic, Chad, the Republic of the Congo, Equatorial Guinea and Gabon. "Others" includes Cape Verde, São Tomé and Príncipe, Nigeria, Mauritania, Ghana, Liberia, Sierra Leone, and the Gambia.
} 
Figure 2A. West African GDP Growth: 1960-2005
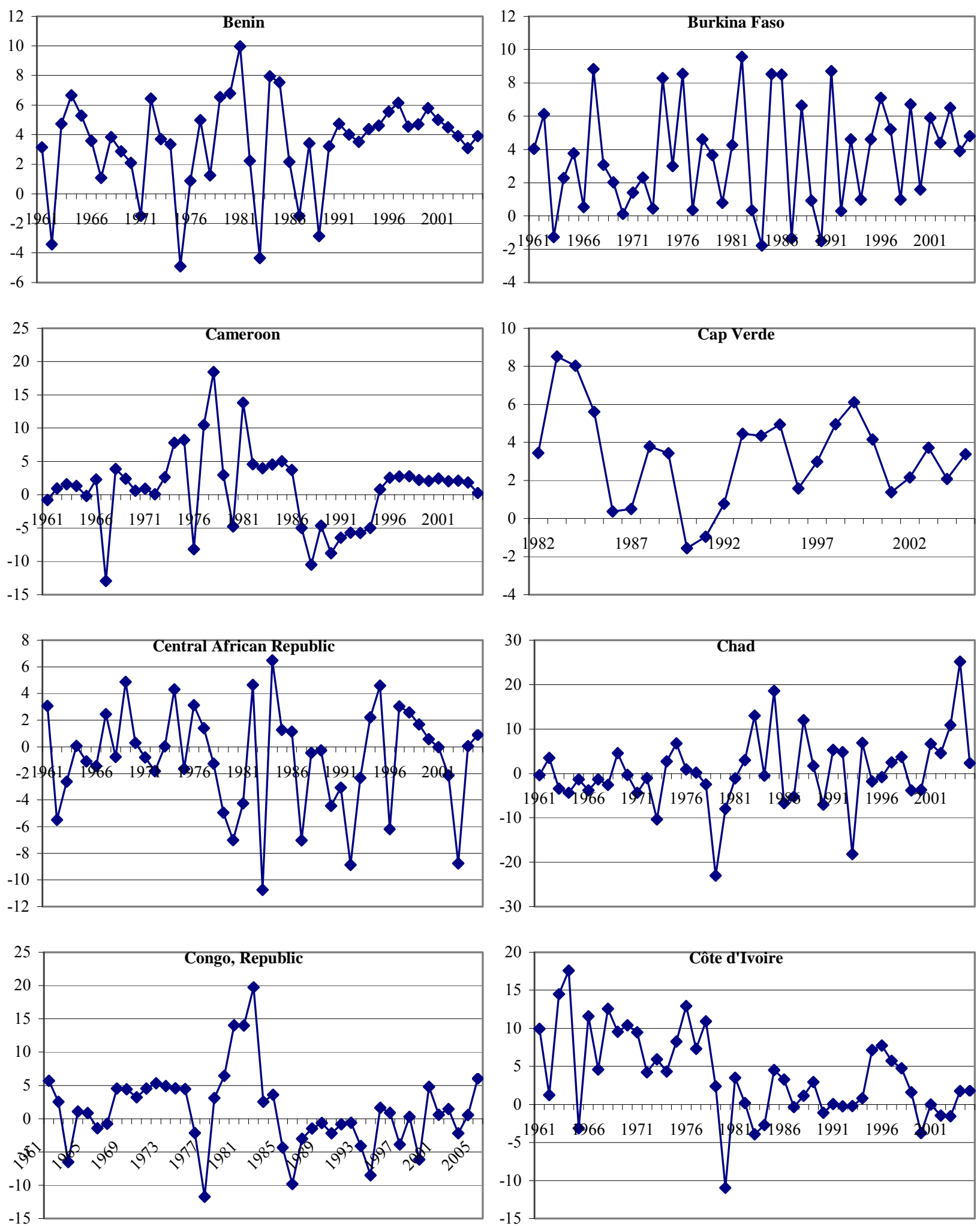

Source: IFS 
Figure 2B. : West African GDP Growth: 1960-2005
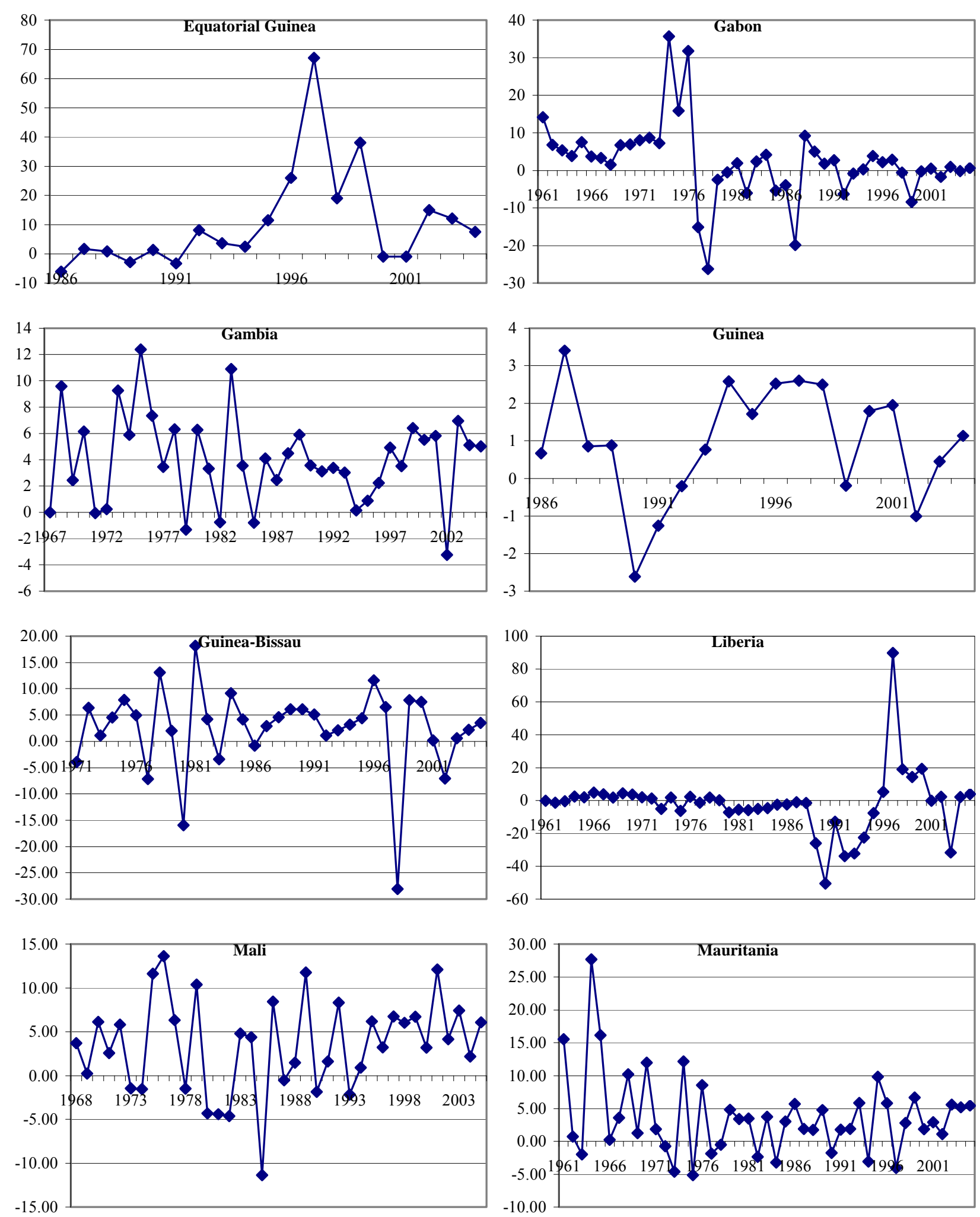

Source: IFS 
Figure 2C: West African GDP Growth: 1960-2005
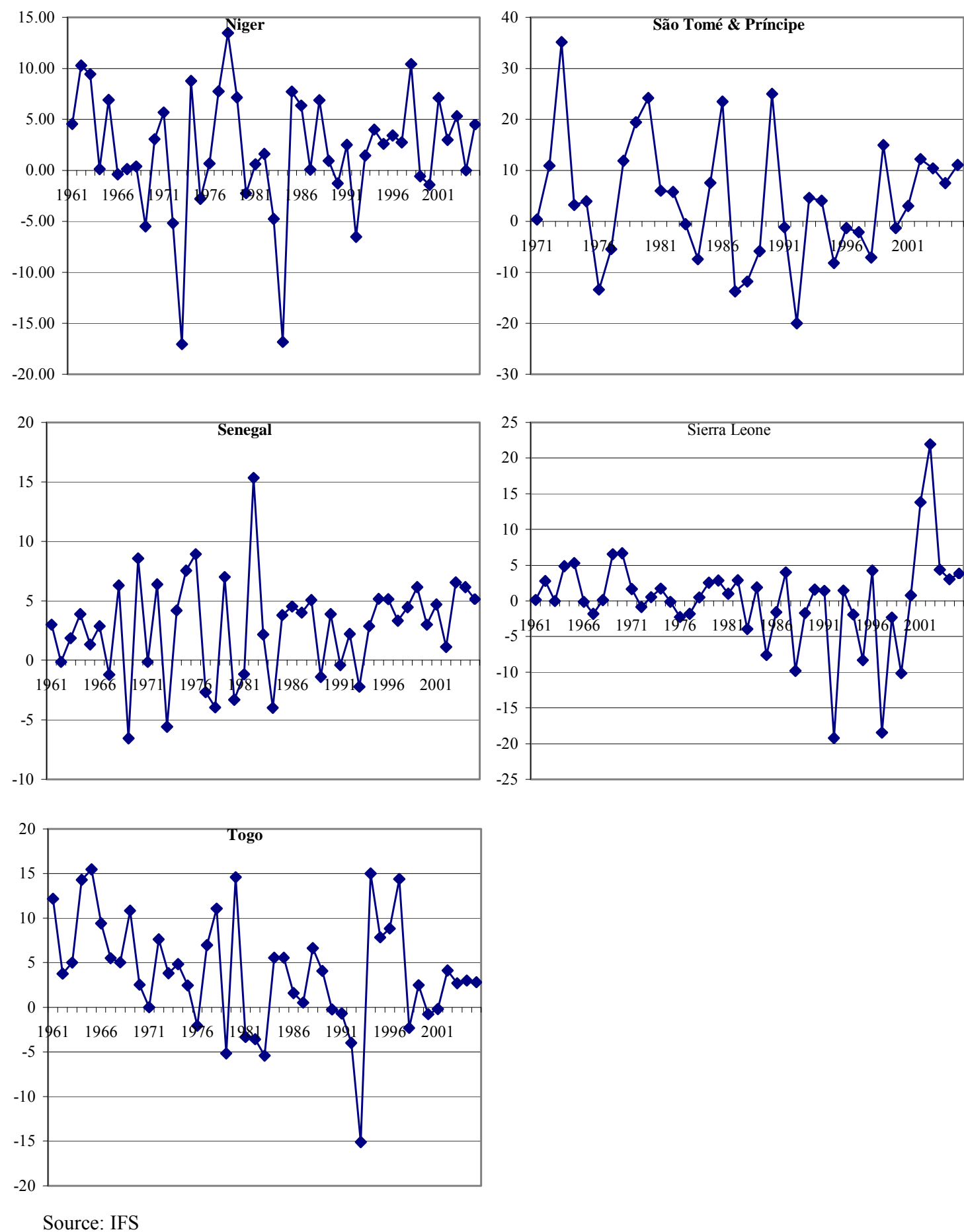


\section{DETERMINANTS OF GROWTH TURNAROUNDS}

The problem in Africa has been variation in growth and an inability to maintain growth for long periods. For this reason, the work of Hausmann, Pritchett, and Rodrik (2005) on growth accelerations is more applicable than other studies to African countries because its methodology singles out the years of turnarounds and tries to relate them to growth determinants, thus allowing us to filter out excessive volatility and concentrate on the most distinct and interesting growth episodes in the region. ${ }^{6}$ Using their methodology, we attempt to explain periods of acceleration, deceleration, and extreme decelerations. We expect external shocks, political changes, economic reforms, and other African-specific variables to be the drivers of turnaround episodes:

- External Shocks: External shocks - not only terms of trade changes and natural disasters but also shocks to remittances - are likely to be key factors differentiating acceleration from deceleration and negative growth episodes. The larger and more persistent the shocks, the likelier the growth rate will be negative.

- Political Changes: It is to be expected that regime change, civil wars, and other local conflicts could explain short-run growth episodes. In general and all else being equal, frequent political changes should disrupt growth by creating an uncertain environment.

- Economic Reforms: Governments that launch economic reforms, such as trade liberalization or labor market or pension reforms, should help accelerate growth.

- Other Africa-Specific Factors: Malaria, the peculiar geography of Africa, and distance from major markets are impediments to growth that are specific to subSaharan Africa. While these variables on their own are unlikely to matter much in explaining growth variation across time, through their interaction with policy variables they might help explain growth turnarounds over time.

\section{A. Identifying Growth Turnarounds}

We define growth turnarounds using a classification of growth accelerations similar to that of Hausmann, Pritchett, and Rodrik (2005). We define the growth rate $g_{t}$ at time $t$ over $n$ years to be the least squares growth rate of GDP per capita (y) from $t$ to $t+n$, and the change in growth rate as

$$
\Delta g_{t, n}=g_{t, t+n}-g_{t-n, t}
$$

We identify a year of growth acceleration as a year $t$ in which the following conditions are satisfied:

\footnotetext{
${ }^{6}$ In studying 80 episodes of growth acceleration around the world since the 1950s, Hausmann et al. (2005) find that investment, trade, real exchange rate depreciation, terms of trade improvements, political regime changes, and economic reforms are more frequent during episodes of acceleration.
} 
(i) Growth is rapid, $g_{t, t+n} \geq 3.0 p p a$.

(ii) Growth accelerates, $\Delta g_{t, n} \geq 2.0 p p a$.

(iii) Post-acceleration output is above pre-acceleration output, $y_{t, n} \geq \max \left\{y_{i}\right\}, i \leq t$. We set the time horizon as five years, i.e. $(n=4)$.

\section{Chart 2: Growth Acceleration Episode}

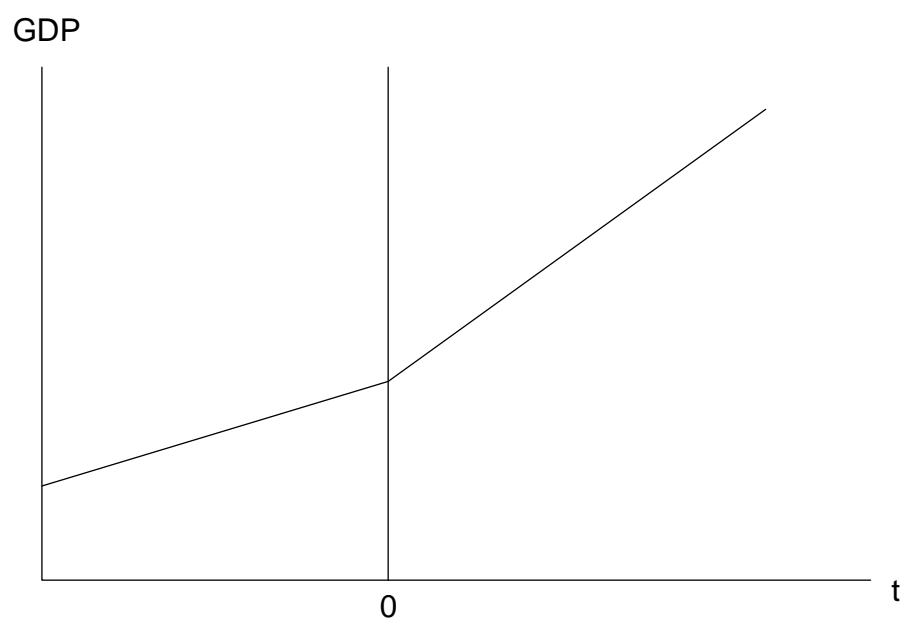

For growth deceleration, we look for years $t$ in which:

(i) Growth is slow, $0.0 p p a \leq g_{t, t+n} \leq 0.5 p p a$.

(ii) Growth decelerates, $\Delta g_{t, n} \leq-2.0 p p a$.

(iii) Post-acceleration output is still above pre-acceleration output $y_{t, n} \geq \max \left\{y_{i}\right\}, i \leq t$.

\section{Chart 3: Growth Deceleration Episode}

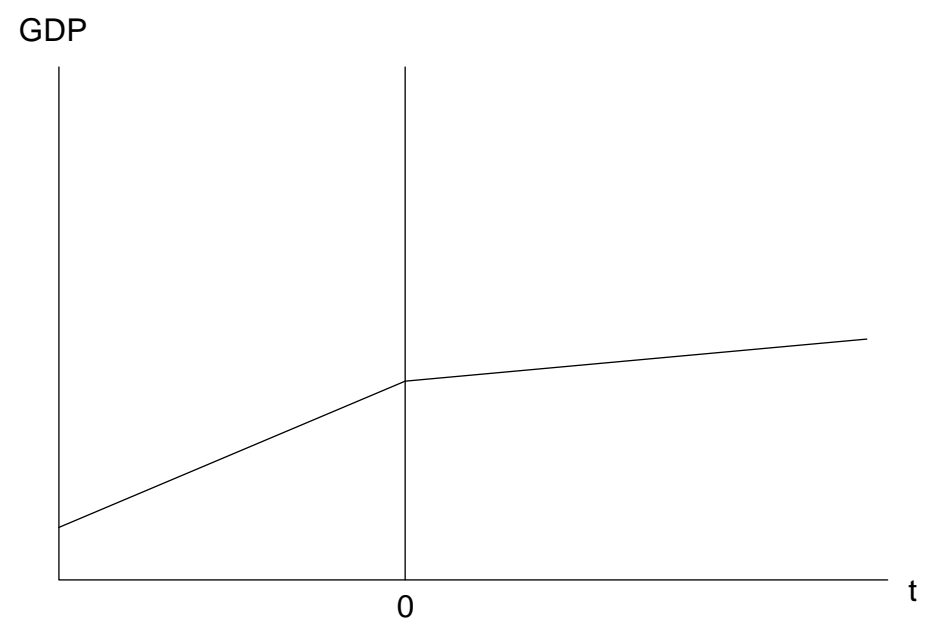


Finally, for growth collapse years, we look at episodes in which growth on average was negative. In particular:

(i) Growth is negative, if $g_{t, t+n}<0 p p a$.

(ii) Growth decelerates, $\Delta g_{t, n} \leq-2.0 p p a$.

(iii) Post-acceleration output is below pre-acceleration output. $y_{t, n} \leq \max \left\{y_{i}\right\}, i \leq t$

\section{Chart 4: Growth Collapse Episode}

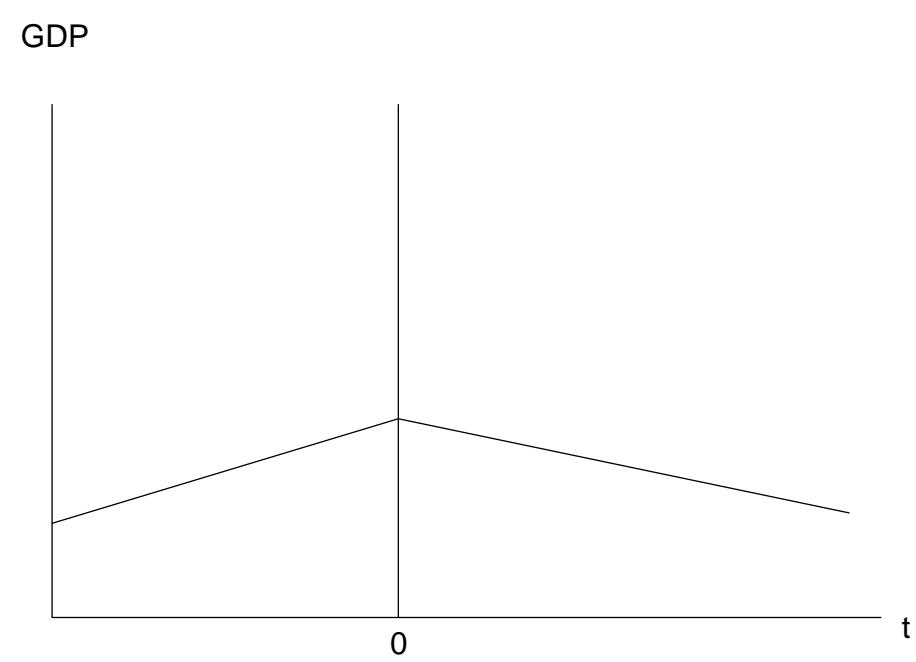

\section{B. Stylized Facts for Turnarounds}

The three types of growth episodes we have characterized above are frequent in Western Africa. For our sample of countries we find 59 periods of growth acceleration, 51 periods of deceleration, and 25 periods of growth collapse (see Table 2).

Interestingly, growth accelerations are frequent throughout the period except in the 1980s (Figure 3). This is not unexpected. In the 1970s, commodity prices boomed. In the late 1990s countries stabilized their economies, investment increased, and aid rose. In the 1980s and early 1990s, on the other hand, commodity prices decelerated, countries suffered from debt overhang, and CFA countries had overvalued exchange rates. This explains why we observe that both deceleration and collapses episodes are more frequent in the 1980s and early 1990s. 
Table 2: Growth Accelerations, Decelerations, and Collapses, 1960-2006

\begin{tabular}{|c|c|c|c|c|c|}
\hline \multicolumn{2}{|c|}{ Accelerations } & \multicolumn{2}{|c|}{ Decelerations } & \multicolumn{2}{|c|}{ Collapses } \\
\hline Country & Starting Year & Country & Starting Year & Country & Starting Year \\
\hline Chad & 1967 & Gambia, The & 1968 & Niger & 1968 \\
\hline Congo, Republic of & 1967 & Cape Verde & 1969 & Cape Verde & 1970 \\
\hline Côte d'Ivoire & 1967 & Equatorial Guinea & 1969 & Chad & 1976 \\
\hline Gabon & 1967 & Togo & 1969 & Ghana & 1980 \\
\hline Ghana & 1967 & Côte d'Ivoire & 1970 & Niger & 1981 \\
\hline Guinea-Bissau & 1967 & Gabon & 1971 & Equatorial Guinea & 1982 \\
\hline Mali & 1967 & Liberia & 1972 & Gabon & 1982 \\
\hline Nigeria & 1968 & Congo, Republic of & 1973 & Congo, Republic of & 1983 \\
\hline Cameroon & 1969 & Ghana & 1973 & Cameroon & 1985 \\
\hline Benin & 1970 & Benin & 1974 & Côte d'Ivoire & 1985 \\
\hline Gambia, The & 1970 & Gambia, The & 1974 & Central African Rep. & 1987 \\
\hline Guinea & 1972 & Guinea-Bissau & 1976 & Sierra Leone & 1987 \\
\hline Chad & 1973 & Nigeria & 1976 & Liberia & 1988 \\
\hline Equatorial Guinea & 1973 & Gabon & 1977 & Equatorial Guinea & 1989 \\
\hline Mali & 1973 & Senegal & 1977 & Senegal & 1990 \\
\hline Niger & 1973 & Côte d'Ivoire & 1978 & Togo & 1990 \\
\hline Senegal & 1973 & Equatorial Guinea & 1978 & Nigeria & 1991 \\
\hline Togo & 1973 & Central African Rep. & 1979 & Gabon & 1993 \\
\hline Côte d'Ivoire & 1974 & Mali & 1980 & Guinea-Bissau & 1993 \\
\hline Cape Verde & 1975 & Mauritania & 1980 & Congo, Republic of & 1994 \\
\hline Central African Rep. & 1976 & Congo, Republic of & 1981 & Chad & 1995 \\
\hline Ghana & 1976 & Liberia & 1981 & Gambia, The & 1996 \\
\hline Burkina Faso & 1977 & Togo & 1981 & Sierra Leone & 1996 \\
\hline Liberia & 1977 & Burkina Faso & 1982 & Central African Rep. & 2000 \\
\hline Benin & 1978 & Ghana & 1982 & Liberia & 2000 \\
\hline Cameroon & 1978 & Guinea & 1982 & & \\
\hline Congo, Republic of & 1978 & Cameroon & 1983 & & \\
\hline Gambia, The & 1978 & Gambia, The & 1983 & & \\
\hline Sierra Leone & 1978 & Guinea-Bissau & 1983 & & \\
\hline Guinea-Bissau & 1979 & Senegal & 1983 & & \\
\hline Chad & 1981 & Niger & 1984 & & \\
\hline Equatorial Guinea & 1981 & Benin & 1986 & & \\
\hline Gabon & 1981 & Chad & 1986 & & \\
\hline Mali & 1983 & Congo, Republic of & 1986 & & \\
\hline Ghana & 1985 & Sierra Leone & 1986 & & \\
\hline Guinea & 1985 & Cape Verde & 1987 & & \\
\hline Mauritania & 1985 & Côte d'Ivoire & 1987 & & \\
\hline Togo & 1985 & Mali & 1987 & & \\
\hline Guinea-Bissau & 1986 & Burkina Faso & 1988 & & \\
\hline Nigeria & 1986 & Mauritania & 1989 & & \\
\hline Gabon & 1988 & Senegal & 1989 & & \\
\hline Gambia, The & 1990 & Guinea & 1990 & & \\
\hline Benin & 1993 & Guinea-Bissau & 1990 & & \\
\hline Mauritania & 1993 & Chad & 1992 & & \\
\hline Côte d'Ivoire & 1994 & Gabon & 1993 & & \\
\hline Guinea & 1994 & Nigeria & 1993 & & \\
\hline Equatorial Guinea & 1995 & Gambia, The & 1995 & & \\
\hline Mali & 1995 & Guinea-Bissau & 1997 & & \\
\hline Niger & 1995 & Mali & 1999 & & \\
\hline Nigeria & 1995 & Cape Verde & 2000 & & \\
\hline Cape Verde & 1996 & Togo & 2000 & & \\
\hline Central African Rep. & 1996 & Equatorial Guinea & 2001 & & \\
\hline Liberia & 1997 & Gabon & 2002 & & \\
\hline Cameroon & 1998 & & & & \\
\hline Gabon & 1998 & & & & \\
\hline Senegal & 1998 & & & & \\
\hline Burkina Faso & 1999 & & & & \\
\hline Chad & 1999 & & & & \\
\hline Ghana & 1999 & & & & \\
\hline Guinea-Bissau & 2002 & & & & \\
\hline Togo & 2002 & & & & \\
\hline
\end{tabular}

Source: Authors' estimates. 
Figure 3: Frequency of Acceleration, Deceleration, and Negative Growth Episodes

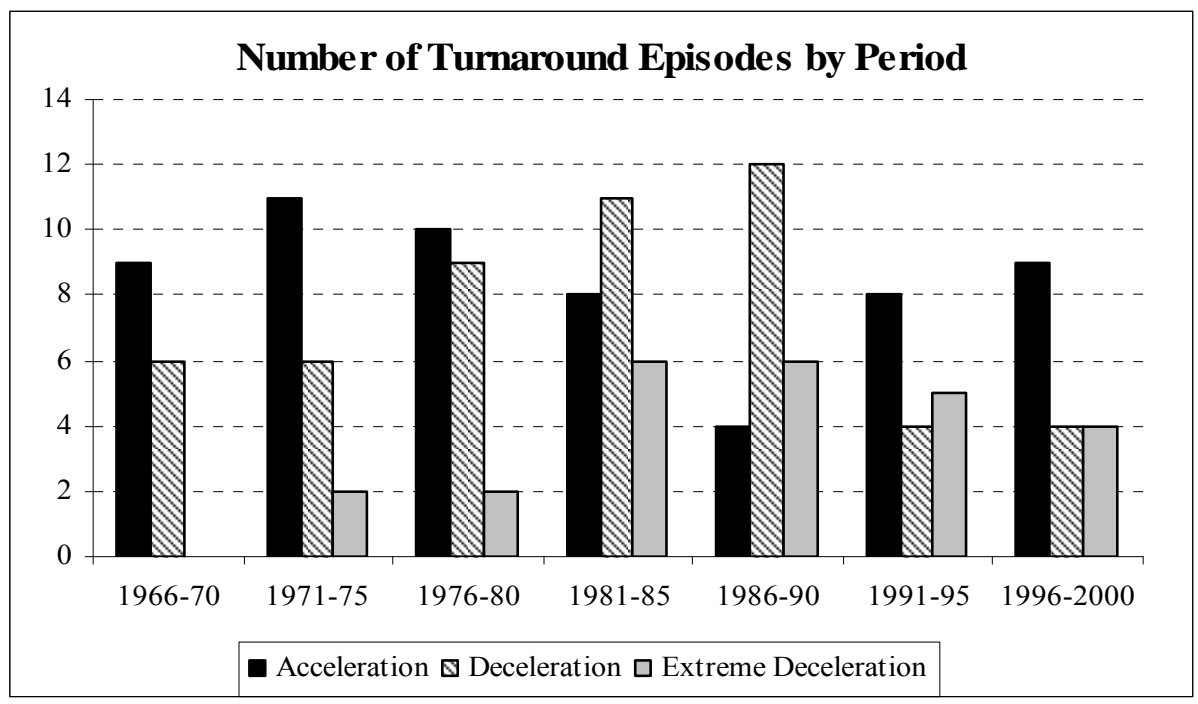

\section{Growth Determinants}

\section{(i) External Shocks}

Because growth can be influenced by such external factors as terms of trade, world demand, remittances, and foreign aid, large changes in these factors could prompt growth turnarounds. Let us look at each of these external shocks in turn.

\section{Terms of Trade}

Many countries in Western Africa are richly endowed with primary agricultural and mineral products. Their prices, which are set on international markets and are very volatile, have a considerable effect on fiscal revenues and incomes. The terms of trade, i.e., the price of one unit of exports compared to one unit of imports, affects income because by making imports cheaper, improvement in the terms of trade acts like a rise in real income (see Funke, Granziera and Imam, 2008).

Negative terms of trade changes tend to have a negative effect on income growth by lowering income from exports and raising the cost of imported goods. Large, sustained changes in the terms of trade, even favorable ones, can cause stress and dislocation, particularly in economies that are inflexible. They can lead to significant shifts in production and employment among economic sectors, which becomes problematic when there are hysteresis effects. Large positive terms-of-trade shocks, by causing an appreciation of the real effective exchange rate, have often had a negative effect on the manufacturing sector in some countries, weakening a potential source of growth (see Funke et al., 2008). Therefore, too large an improvement in the terms of trade might have a negative impact in the longer run. The data, which are obtained from World Development Indicators (2008), is defined as export price divided by import price.

Terms of trade changes has varied more widely in Africa than in any other region. Several explanations have been advanced, but the essential argument is that African countries 
produce mainly agricultural goods and minerals, whose prices have historically been more volatile than those of other goods. Most countries in our sample are undiversified producers, exporting only a few primary commodities. Because none of the countries we are looking at is a dominant producer of a specific primary good, we can safely assume that terms of trade changes are exogenous.

The terms of trade of West Africa as a whole appears not to be extremely volatile (see Figure 4), perhaps because of a diversification effect, the fact that some countries, e.g., those in CEMAC, are mainly oil exporters, which do well when oil prices go up, while others, such as those in WAEMU, are mainly oil importers that do badly when oil prices go up. The combination has the effect of reducing variability for the region as a whole.

Figure 4: Average Percent Change in Terms of Trade for Sample Countries, 1963-2005

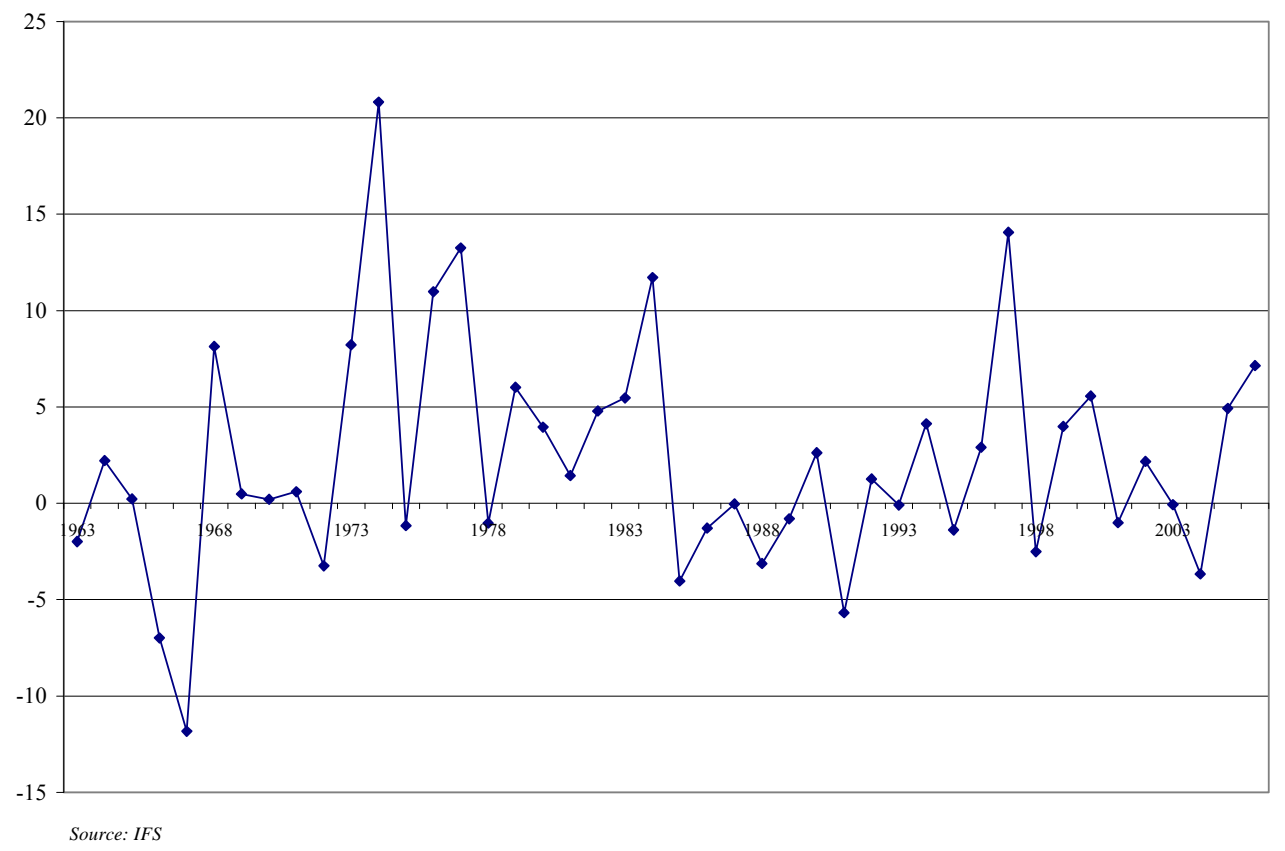

The terms of trade changes for WAEMU and CEMAC separately, however, are very large, often times more than 10 percent per year (Figure 5), confirming that volatility of terms of trade for individual countries are very large indeed. 
Figure 5: Annual Percentage Terms of Trade Changes in WAEMU and CEMAC, 1967-2005

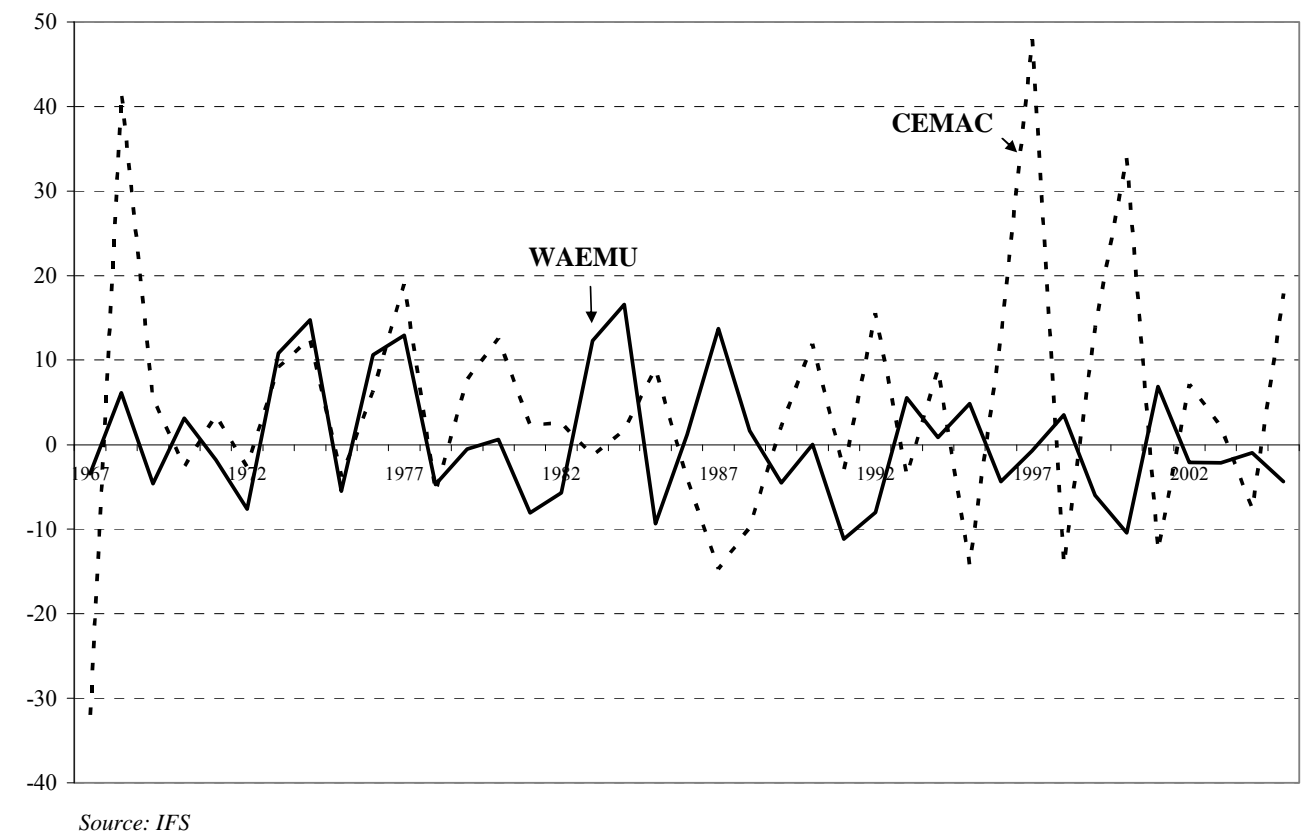

\section{Remittances}

Remittances-financial flows arising from the cross-border movement of nationals of a country - depend largely on the percentage of the population that has migrated abroad. For the poorest countries, remittances often exceed other sources of foreign exchange, such as trade, bank lending, or foreign aid. Remittances in SSA grew steadily between 1973 and 2005 (see Figure 6). They could help explain the growth turnaround observed in recent years.

Figure 6: Remittances as a Percent of Gross National Income in Western Africa, 1973-2005

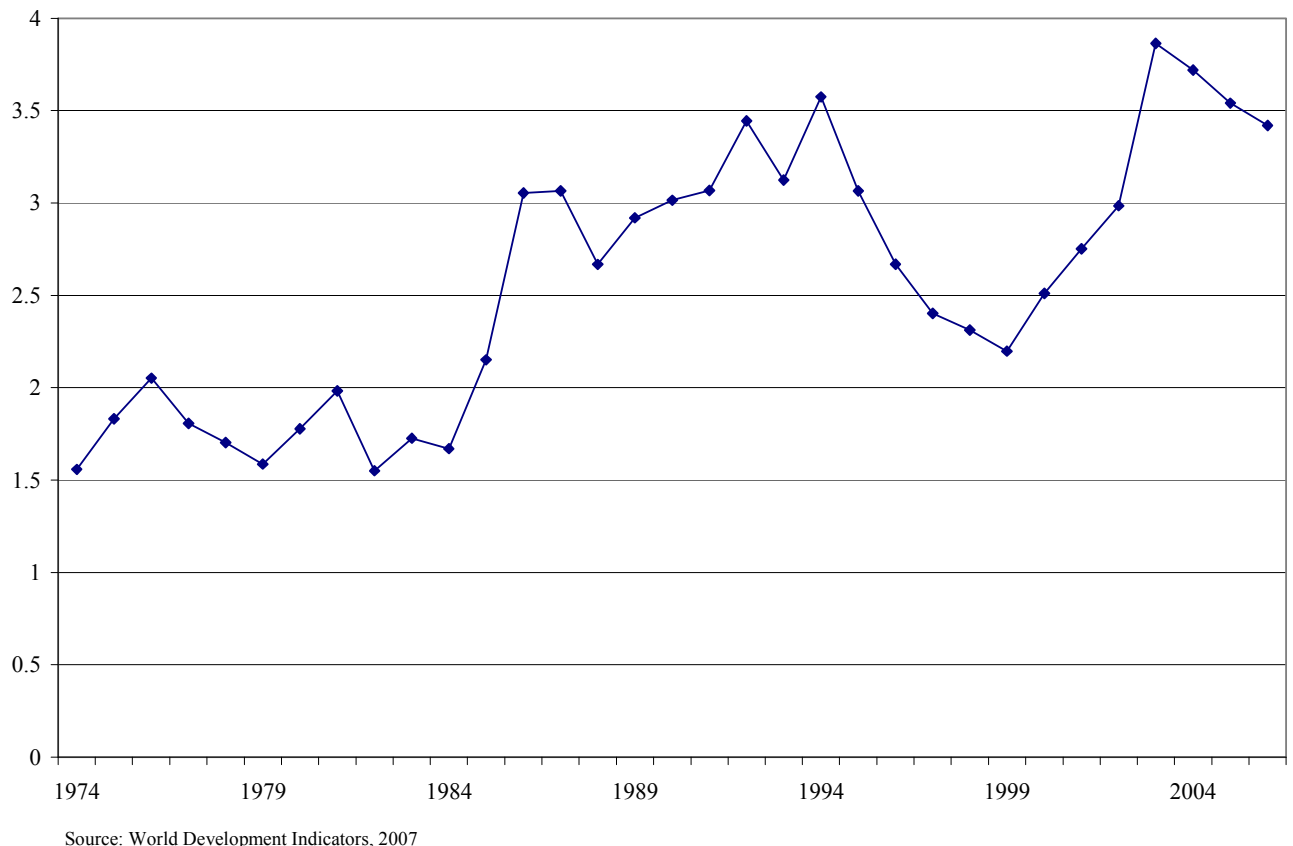

Source: World Development Indicators, 2007 
Remittances are different from other types of capital flows. First, they are "unrequited"- they do not result in claims on assets or other contractual obligations. Once transferred to a country, remittances cannot be withdrawn, unlike purchases of financial or productive assets, which can be liquidated and repatriated. Moreover, flows of remittances are remarkably stable over time, with nothing of the herd-like behavior of bank loans observed during crises. Whereas other forms of cross-border economic activity may lead to income volatility and insecurity in national economies, remittances actually smooth the incomes of domestic residents because they often increase when the domestic economy is in trouble (see Gapen et al., 2008). In short, financial transfers from migrant workers help to insulate developing countries from the forces of the global economy.

Remittances come from countries where people have migrated, which means not only Western Europe and the U.S. but also other countries in the region. Nigeria, for example, receives substantial remittances from abroad, but its large population of foreigners also sends considerable amounts abroad.

One problem for our purposes is that remittance data are inherently underreported; much of the flow does not come through the banking system. Among various informal methods of transferring money are personal transport of funds and money sent through the mail or through a third party. Unregistered channels are often pursued because undocumented immigrants generally do not have access to banks and because many developing countries lack nationwide banking networks, making it difficult to transfer money to outlying areas. So the remittance data from WDI probably underestimates the real inflow of money.

\section{Foreign Aid}

Aid plays a disproportionately larger role in the growth process in Africa than in other regions. How does it affect growth? Until recently, the results were ambiguous: Some studies found that aid did not help growth, arguing that it was mostly wasted. Others found aid to be effective, holding that had it not been for aid, growth in Africa would have been even more disappointing. In the 1990s, it was argued that the effect of aid was conditional on other factors, notably government policies (Burnside and Dollar, 2000): Countries with good economic policies benefited from aid, those with bad policies did not enjoy the fruits of aid.

The problem with earlier studies is that they aggregate all aid together, whether it is humanitarian or project aid, and implicitly assumed that the aim of all aid was simply to raise growth. In fact, the aim of aid is not always to raise growth. Aid after natural disasters, for example, is intended to meet people's immediate needs. This type of aid on its own does not create productive capacity and should not be expected to raise long-term growth. As was particularly clear during the Cold War, much aid is also given for political reasons, for instance, to strengthen an ally by providing "military" aid. Again, this type of aid cannot be expected to be productive and hence good for growth. However, aid that supports capital investment in infrastructural projects such as roads and utilities could be expected to raise growth (see Clemens, Radelet, and Bhavnani 2004), as could aid in the form of budget support, if it is spent efficiently.

Therefore, when we look at aid, we should bear in mind that not all aid is equal. If we break it down by category, differentiating between aid that has a long-term effect on growth (capital expenditure); aid that has a short-term effect (current expenditure); and aid that is 
purely humanitarian, we would expect the first two categories to have a positive effect on growth, while humanitarian aid could have a negative correlation with growth because of the selection bias (see Figure 7). It is notable from Figure 7 below that aid has risen dramatically since 2002, reflecting the push by the World community to achieve the Millennium Development Goals. Much of the aid increase was in the form of forgiving debt, but much was also an increase in transfers from richer to poorer countries. The data we use for foreign aid are obtained from the OECD DAC.

Figure 7: Aid by Category, 1973-2005

(in million of US dollars)

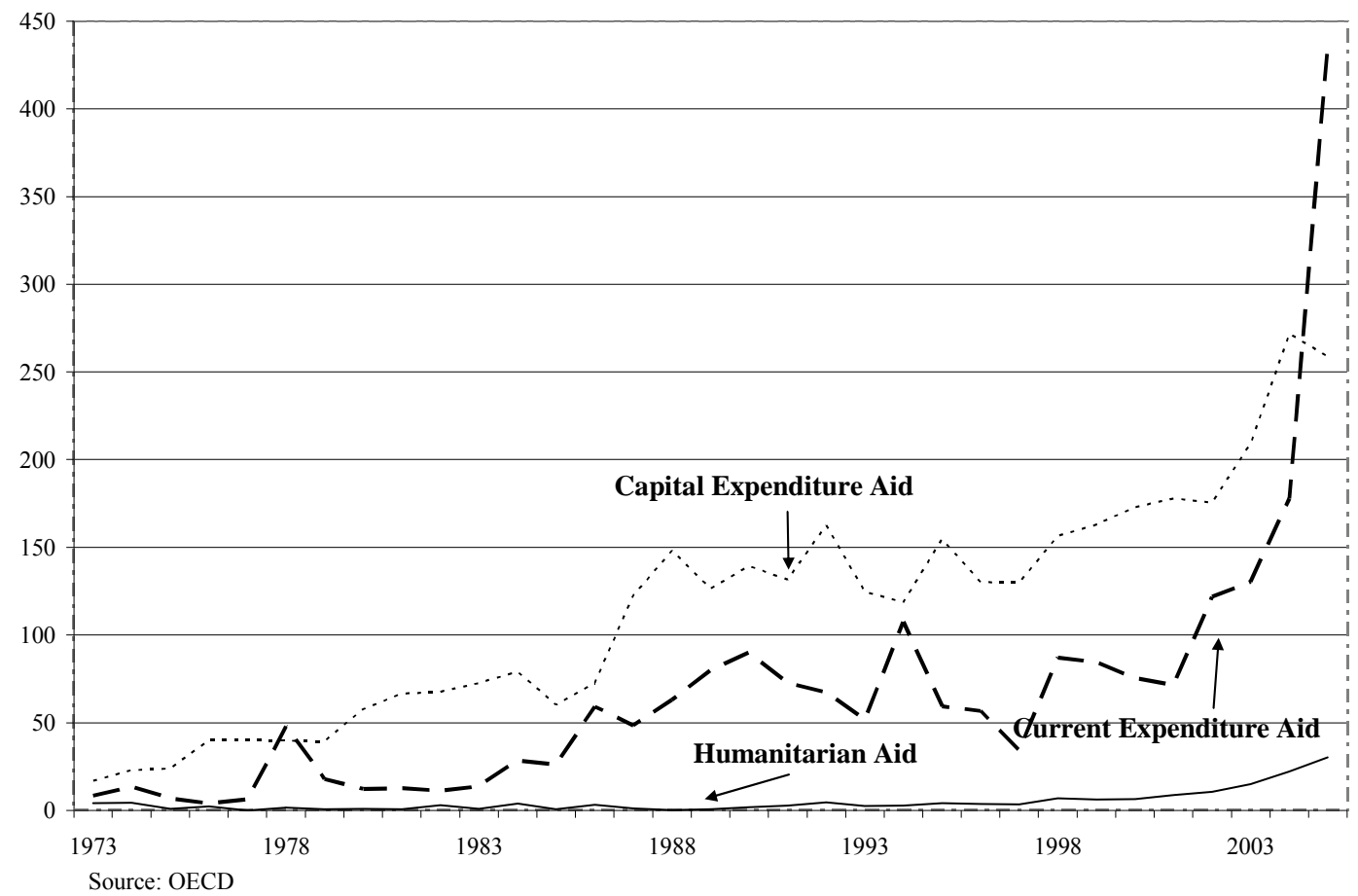

World Demand

Although their share of total international trade has been declining for several decades, the countries in SSA are closely connected to the world economy. Increases in world growth are expected to have a positive effect on demand for SSA exports and output. We therefore include world real GDP growth as a possible determinant of growth turnarounds in West African countries. (Our source for this variable is the World Bank's World Development Indicators.) Historically, world real GDP growth has been rather volatile, swinging substantially over short time periods. In recent years, world growth has indeed been high, which might be an explanation for why Western African countries might have seen positive turnarounds. 
Figure 8: World Real GDP Growth, 1980-2008

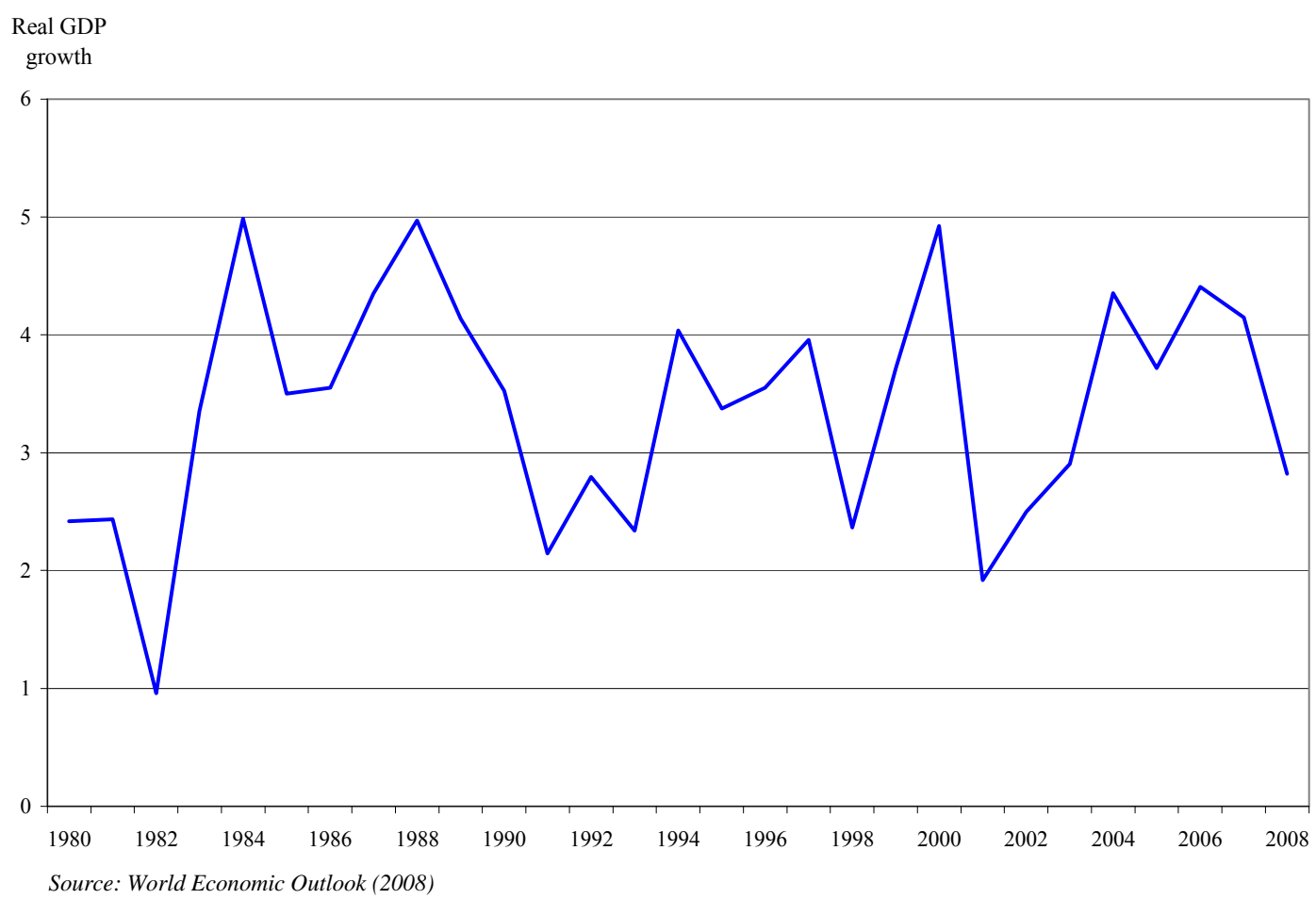

\section{(ii) Political and Institutional Changes}

Political and institutional factors crucially affect economic development. Institutions are one medium through which factors conventionally used to explain differences in economic performance (geography, economic stability, trade liberalization, etc.) get transmitted. They matter because shocks are handled less well by countries with weak institutions. The question of causality is crucial: Do good institutions lead to growth, or does growth lead to good institutions? North (1994) and many later studies (e.g., Acemoglu Johnson, and Robinson, 2001), have argued that the causality runs from institutions to growth. Kaufmann and Kraay (2002) have shown that increases in per capita income have no significant relationship with governance improvement - their findings suggest that income explains only 10 percent of the variations observed in institutional quality.

Lack of constraints on leaders means that taking political control yields greater rewards and losing it yields greater losses, making political fights more common. Leaders pursue short-term policies that guarantee their hold on power at the expense of longer-term policies that are good for growth. As a result, there is political volatility, entrepreneurs will opt for sectors of the economy from which they can quickly withdraw their capital if needed, thereby enhancing volatility further (Easterly and Levine, 1997).

Measuring changes in institutional and political factors is bound to be imprecise because these variables are vague, complex, and multidimensional. We therefore concentrate on a institutional aspects that are commonly perceived as growth determinants in the economics literature and are monitored by several institutional development organizations. These are war/conflict, governance, legal origin, and monetary institutions. Some of these are particularly relevant to SSA. 


\section{War/Conflict}

Over the last four decades more than a third of the region's countries have experienced civil strife. The economic effects of conflicts are, to different degrees, (i) a diversion of resources toward unproductive activities; (ii) a reduction in the capital stock and in investment rates that results from the uncertainty of outcomes or the risk of expropriation; (iii) an increasing military burden that burns up public resources that could have been invested in infrastructure, education, health, etc.; and (iv) a loss of human and social capital (see Collier and Hoeffler, 2006 ). In addition, the psychological impact of violence takes a long time to heal. We identify years of conflict based on the Armed Conflict Dataset Book, ${ }^{7}$ giving priority to the worst episodes, denominated as "war" in the database (those which caused at least 1,000 battle deaths a year). As can be seen in Figure 9, conflicts have been highly prevalent in Western Africa throughout the period, though less frequent in the years of the commodity boom of the 1970s.

Figure 9: Conflicts over time in Western Africa, 1960-2005

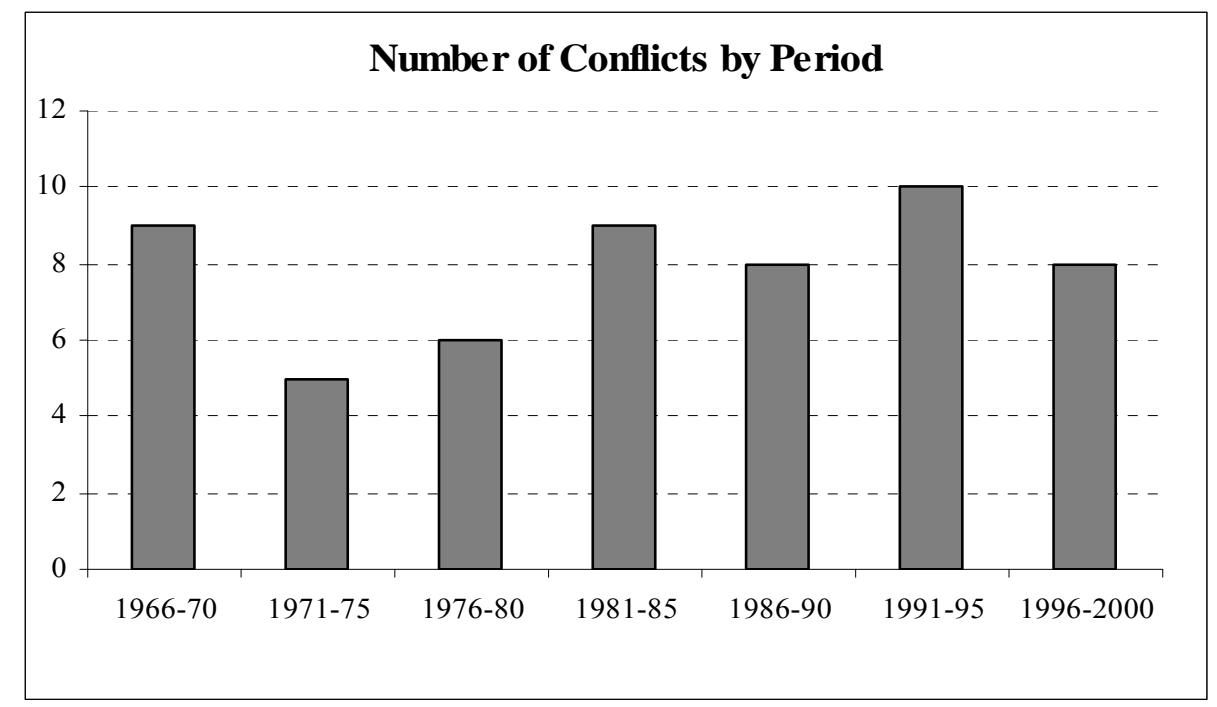

\section{Governance}

Governance is understood as (i) the process by which governments are selected, held accountable, monitored, and replaced; (ii) the capacity of governments to manage resources efficiently and formulate, implement, and enforce sound policies and regulations; and (iii) the respect of citizens and the state for the institutions that govern economic and social interactions among them (Kaufmann et al. 1996).

We use four governance variables from the International Country Risk Guide (corruption, bureaucratic quality, accountability, and law and order) and two indices from Polity $I V$ that aim to measure the degree of democratic rule (Polity 2 Index) and the number of years

\footnotetext{
${ }^{7}$ This dataset is available at: $\mathrm{http}: / / \mathrm{www}$. prio.no/cscw/armedconflict.
} 
without major regime change. ${ }^{8}$ We expect that improvements in governance indicators will have a positive effect on growth and rising corruption will have the reverse effect.

Corruption is the aspect of governance that in practice appears to have mattered the most in SSA. Countries in SSA exhibit relatively higher levels of corruption than those elsewhere. This is commonly perceived as a major constraint on efforts to accelerate growth in order to achieve internationally and nationally mandated development goals. ${ }^{9}$ Corruption is often understood as the abuse of public office for private gain, whether material or political. Several explanations of the links between corruption and growth have been advanced. In any case, corruption undermines public confidence in the government's ability to manage the economy in the interest of the people (see Abed and Gupta, 2002). Given that corruption not only brings benefits to those in control of power but also allows them to manipulate institutions to their advantages, it tends to be self-perpetuating unless drastic reforms are undertaken to eradicate it.

\section{Legal Origin}

Institutions are affected by colonial history. Djankov et al. (2003) emphasize the influence of the colonization process on both institutional patterns and current economic performance. They distinguish between countries colonized by England (e.g., Nigeria, Ghana) that inherited the common law system and those colonized by France (e.g., Senegal), Spain (Equatorial Guinea) and Portugal (e.g., Cape Verde) that inherited the civil law system. The argument is that the common law system provides better protection of property rights and promotes an efficient, modestly sized state. The civil law system is considered to favor a state that is less efficient and more interventionist. ${ }^{10}$ The variation in growth across country groups could therefore in part find its root in different legal origins of countries.

\section{Monetary Institutions (CEMAC/WAEMU)}

WAEMU and CEMAC countries have much in common as members of the CFA franc zone. The institutional heritage of the 13 CFA countries differs substantially from that of most other countries in Western Africa. Given the monetary, and to a lesser extent fiscal, discipline imposed by their membership in the CFA franc club, these countries were not as much affected by the inflation and exchange depreciation that damaged much of Africa

\footnotetext{
${ }^{8}$ Although it might be expected that a long period of stability could be more conducive to economic growth, Mancur Olsen's (1982) argued that a government that is in power too long will form a distributional coalition that will have incentives to influence policies in its favor. These policies will tend to be protectionistic and antitechnology, such as protecting cotton growers from competition, and will therefore hurt economic growth. Since the benefits of these policies are selective incentives concentrated among the few coalition members while the costs are diffused throughout the whole population, they will face little public resistance. Hence as time goes on and distributional coalitions accumulate in greater and greater numbers, the nation burdened by them will fall into economic decline.

${ }^{9}$ See for instance Transparency International (http://www.transparency.org/).

${ }^{10}$ Acemoglu, Johnson, and Robinson (2001) suggest distinguishing between settlement (where colonialists resided) and exploitation (where they just extracted natural resources) colonies. Given that West Africa was never settled on a large scale, we will not need to proxy for that.
} 
during the 1970s and 1980s, though the 1994 devaluation of the CFA franc, reflecting a high real effective exchange rate appreciation over the 1980s, was an exception in an otherwise very stable monetary arrangement.

However, there is one major difference between CEMAC and WAEMU countries: the former tend to be mostly oil producers and the latter mostly oil importers. As a result, institutional arrangements differ in many aspects. The group of other countries is composed mainly of former English colonies and their exchange rate arrangements are not as tightly pegged throughout the 1960-2006 period.

\section{(iii) Economic Reforms}

Countries that launch reforms like economic liberalization, inflation stabilization, and financial reform could arguably be setting up the conditions for growth acceleration, while those stopping or reversing them should promote deceleration or growth collapses.

\section{Economic Liberalization and Financial Sector}

After decades of implementing import substitution policies, several countries started liberalizing their economies starting in the mid-1980s. Excessive government intervention and trade protectionism could create distortions and bring the economy below the production possibility frontier determined by free markets. Removal of these distortions would then bring about a period of higher growth. We will use the Wacziarg-Welch dataset (2008) to identify a year of significant economic liberalization and an additional variable that singles out all the years in which an IMF-WB structural adjustment program was launched. According to this dataset (see Table 3), episodes of trade liberalization in sample countries took place between 1985 (The Gambia and Ghana) and 2001 (Sierra Leone).

Table 3: Years of Economic Liberalization in Sample Countries

\begin{tabular}{ll}
\hline Country & Year \\
\hline Benin & \\
Burkina Faso & 1990 \\
Cameroon & 1998 \\
Cape Verde & 1993 \\
Cote d'Ivoire & 1991 \\
Gambia, The & 1994 \\
Ghana & 1985 \\
Guinea & 1985 \\
Guinea-Bissau & 1986 \\
Mali & 1987 \\
Mauritania & 1988 \\
Niger & 1995 \\
Sierra Leone & 1994 \\
\end{tabular}

Source: Wacziarg and Welch (2008)

We also try to capture the more specific impact of financial reforms using the share of domestic credit-to-GDP ratio, taken from the WDI. We note, however, that a priori the link 
between financial reform and financial depth is not clearly determined, implying that this variable may indeed be endogenous to economic growth. ${ }^{11}$

\section{Macroeconomic Instability Proxy}

Macroeconomic instability has had very different effects on different countries in Western Africa. Taking inflation as our indicator of macroeconomic instability, we use data on CPI inflation from WDI. While CFA countries were spared high inflation because they had a credible central bank, this was not necessarily the case for other Western African countries. Although inflation did not reach hyperinflation levels, it was high in many episodes and could have represented a major distortion to economic allocation and growth.

\section{(iv) Africa-Specific Factors}

Tropical climate, high prevalence of disease, distance from major markets, being mainly primary producers are seen as impediments to growth that are relatively more influential in Western African countries than other regions in the world. Because some of these variables are constant through time, they cannot explain growth variation across time, but even they may still affect the likelihood of growth turnarounds. For instance, coastal countries that are more integrated into the world economy could experience higher output volatility because they are more exposed to global volatility, and thus may be more likely to show growth accelerations or decelerations. The interaction with policy variables might also explain growth turnarounds.

\section{Rainfall}

Because the region as a whole is still largely agrarian, factors that have a direct effect on agriculture growth, especially rainfall, will also have major effects on growth. The volatility of growth in Africa is in part due to variation in rainfall. Droughts like the one Niger experienced in the mid-2000s have clearly been associated with negative growth episodes. Interestingly, looking at rainfall between 1950 and 2004 in the Sahel region, which covers a large part of our sampled countries, it was above average standardized with respect to 1950-2004 before the 1970s and below for most years after. The growth upswings and downswings observed in many countries in the region may be partly driven by rainfall and drought.

\footnotetext{
${ }^{11}$ The Wacziarg and Welch index, an update of the Sachs-Warner dataset, aims to determined the year of trade liberalization, but we use it as a proxy of overall economic liberalization because trade liberalization has been usually undertaken in the course of liberalizing other sectors, and also because Rodriguez and Rodrik (2000) have argued that the way trade liberalization was determined in this list takes into account both trade- and nontrade-related sectors.
} 
Figure 10: Mean Rainfall in the Sahel

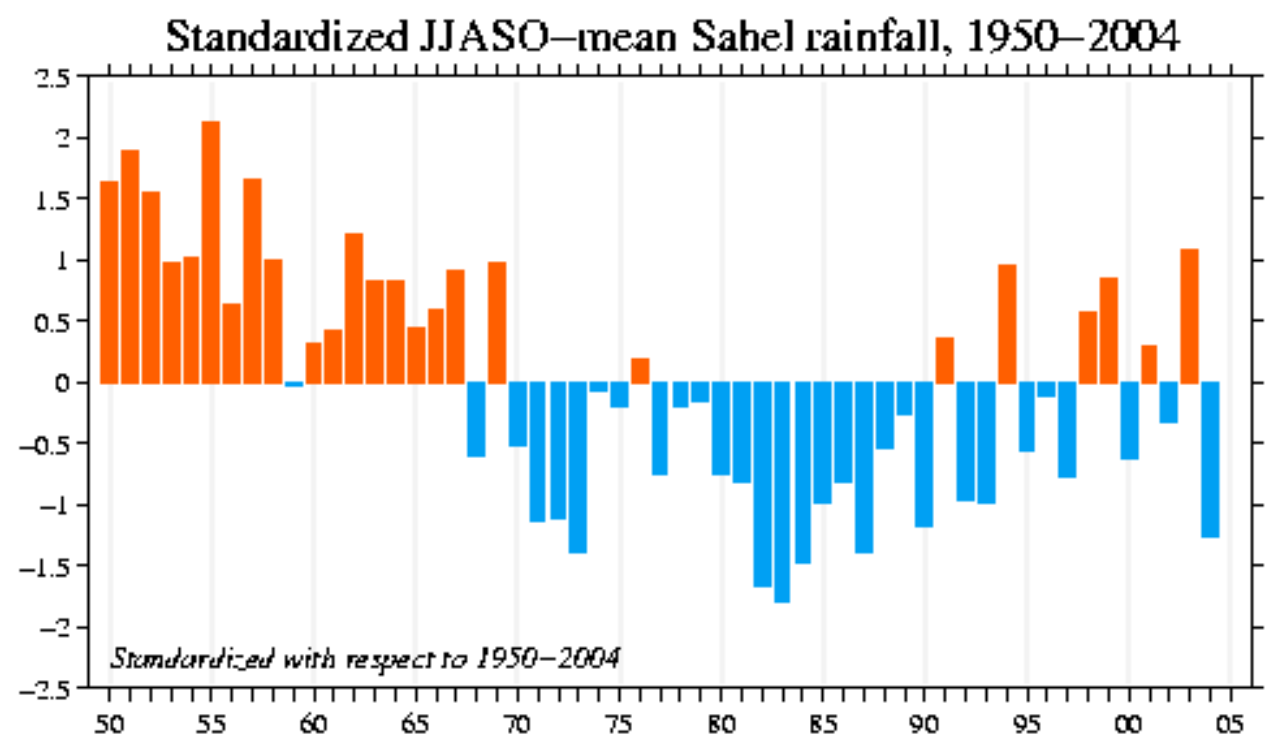

Using rainfall data from NASA, we test both absolute rainfall and rainfall as a share of GDP, to adjust for its impact on income growth.

\section{Ethnic Fractionalization}

Tensions among different population groups can evidently affect economic growth, even if they do not lead to open conflict, through their effect on political stability and institutions. ${ }^{12}$ Fractionalization is particularly complex in Africa, where many countries are fragmented due to internal religious, ethnic, language, and other cultural differences. The relationship between fractionalization and growth is, however, not necessarily monotonic. In fact, Collier (2000) has found that the negative effect of fractionalization on economic development weakens when ethnic fractionalization is extreme, that is, when there are a very large number of small ethnic groups.

We look here at ethnic fractionalization, for which relatively precise measures have been developed. ${ }^{13}$ However, while ethnicity may seem to be a simple concept, in practice

\footnotetext{
${ }^{12}$ For instance, because fractionalization can lead to increased rent-seeking, it often appears negatively correlated with it in statistical analysis (Aghion, Alesina, and Tribbi. 2004).

${ }^{13}$ Although cultural differences related to language, religion, and other factors have been evoked as important in explaining variations in economic development between countries, we do not analyze their potential impact on growth turnarounds. The idea behind cultural predetermination of economic development is that different cultures produce individuals with different values, which manifest themselves in different behaviors. Some behaviors are more useful for economic development than others, so countries with a culture that has more progrowth forms of behavior in terms of attitude toward work, saving, and education, will do better economically (e.g., Huntington, 2000). However, the concept is highly questionable. Often two societies at different points in time can produce very different behavior patterns. For example, half a century ago Myrdal had doubts about non-Western cultures, notably East Asian ones. Today, the success of Buddhist Thailand, Hindu India, and Muslim Malaysia suggest that culturalist/religious explanations should be dismissed. This is because cultures
} 
there are complications. When communities intermingle, it becomes harder to determine the degree of ethnic fractionalization. ${ }^{14}$ Furthermore, during periods of stress, the concept of ethnicity might appear where it did not previously exist. For example, an individual's selfidentification with a group can be changed by political or economic shocks. In Somalia, for instance, until the civil war of 1991, 85 percent of Somalis considered themselves as part of the same group, but with the civil war, clans become the new dimension of ethnic cleavage (Mozzafar and Scarritt, 1999).

For lack of better data we will define ethnic fractionalization as the probability that two individuals taken at random in a population will belong to different ethnic groups (Easterly and Levine, 1997). A value of 0 means everyone is from the same group, and a value of 1 means that everyone is from a different group. Of the 21 most fractionalized countries, 20 are in sub-Saharan Africa. The ethnic basis can be considered exogenous over a short period of a few decades.

\section{Distance/Landlockedness}

Africa's geography is peculiar for several reasons. First, relative to other regions, it is far from major markets. This means higher costs to transport goods, which is a cost disadvantage. Second, and related, many countries within Africa are landlocked, which further raises transportation costs. On average Africans tend to live far from the coast. Coastal regions in Africa have in general done better than landlocked ones (Gallup and Sachs, 2001) because by facilitating transportation, they are typically better able to set up a manufacturing base whose products need to be exported, which is often considered the basis for development. Manufacturing regions, through agglomeration effects, often generate a positive spiral in growth. ${ }^{15}$ We will therefore test whether the proportion of the population close to the coasts has a positive effect on growth or not, and similarly examine whether Western African countries located at more western latitudes (closer to the coast) have a higher probabilty of experiencing growth accelerations.

\section{The Climate and Malaria}

Climate is another geographical factor deemed important for growth. Most African countries in our group are either tropical or desertic. Both characteristics have serious

\footnotetext{
have elements that have both positive and negative effects on growth, with the positive dominating the negative over some periods and the opposite happening over other periods. It is also difficult to incorporate this concept into statistical analysis because culture cannot be easily quantified. Most culturalists define culture very broadly, ignoring dramatic ethnic and religious cultural differences within the same country, especially in Western Africa.

${ }^{14}$ For example, the ethnic fractionalization of the former Yugoslavia was accentuated by groups who differed by their religion (Catholic, Orthodox Christians and Sunni Muslims), but who were often intermarried, with their progeny labeled "Chrislims."

${ }^{15}$ In Africa it has often been said that there is an "urban bias" because governments favored the development of urban over rural regions. All else being equal, this does not affect the argument that coastal urban centers are better for income growth.
} 
negative effects on growth. Unlike temperate areas, tropical areas have a higher burden of disease. ${ }^{16}$ Diseases, malaria in particular, have a very depressing effect on growth. ${ }^{17}$ In Western countries many diseases were vanished by better hygiene, which creates a potential endogeneity problem, but malaria is not a disease like tuberculosis or diarrhea that is caused by deficient living conditions. It is determined mainly by climate and ecology. ${ }^{18}$ This means that, particularly in Africa, we can assume it to be largely exogenous (see Gallup and Sachs, 2001). According to Gallup and Sachs, "none of the other tropical diseases had a significant negative correlation with economic growth, even at the $10 \%$ level, after controlling for malaria in these regressions" (p. 94), which implies that malaria is unique. The data we use, from Gallup and Sachs, represents the share of the population affected by malaria.

\section{Nonfuel Primary Exporters}

The Prebisch-Singer hypothesis observes that the terms of trade between primary products and manufactured goods tend to deteriorate over time. This observation was based on long-term data suggesting that the terms of trade for exporters of primary commodities other than fuel-related commodities did have a tendency to decline over time. One reason advanced is that the income elasticity of demand is greater for manufacturing/industrial goods than for primary nonfuel products. As economies develop, demand for manufactured goods increases faster than demand for primary products (see Ocampo and Parra, 2003). In fact, the recent surge in commodity prices reflects essentially a boom in fuels and minerals, rather than food prices, despite the perception that food prices have gone up substantially (see Figure 11). All else being equal, if the Prebisch-Singer hypothesis holds, nonfuel primary exporters are more likely to stagnate than mineral and fuel producers simply because demand for their goods on international markets declines relative to the rest of the world.

\footnotetext{
${ }^{16}$ Some, like the philosopher Montesquieu, made the point that climate might have an effect on temperament and work effort. We will ignore it.

${ }^{17}$ Microeconomic studies suggest that the cost of malaria on human capital is not that large as measured by the cost of prevention, treatment, and loss of productivity, except perhaps for the very poorest in society. Macro studies show, however, that the costs can be very large indeed, as high as 1 percentage point of economic growth a year (see Malaney, Spielman, and Sachs,. 2004). This discrepancy is in part due to the fact that poor health creates numerous negative externalities that micro studies do not capture. The costs of malaria are multiple. Besides the direct human toll and the cost of treatment, the indirect effect on development might be most severe. People with malaria might invest less in their education if they know they will not live long, thereby diminishing human capital. The drain of malaria on family finances means that savings, an engine of growth, will be minimal, leading to inability to build up a stock of capital. Malaria may affect foreign direct investment, since international companies that seek to extract natural resources may not want to invest in malaria-infected areas because health costs would drive up total costs tremendously. Similarly, trade might be constrained because investors might be less willing to travel to malaria areas. Other sectors, such as tourism might be slower in developing. Migration into malaria regions might be hampered, affecting economic development there.

${ }^{18}$ Malaria has indeed been eradicated in more developed regions, but only through large investments mainly aimed at altering the ecological systems that host malaria.
} 
Figure 11: Agricultural Raw Material, Metals, and Petroleum Price Indexes, 1990-2007 $(2000=100)$

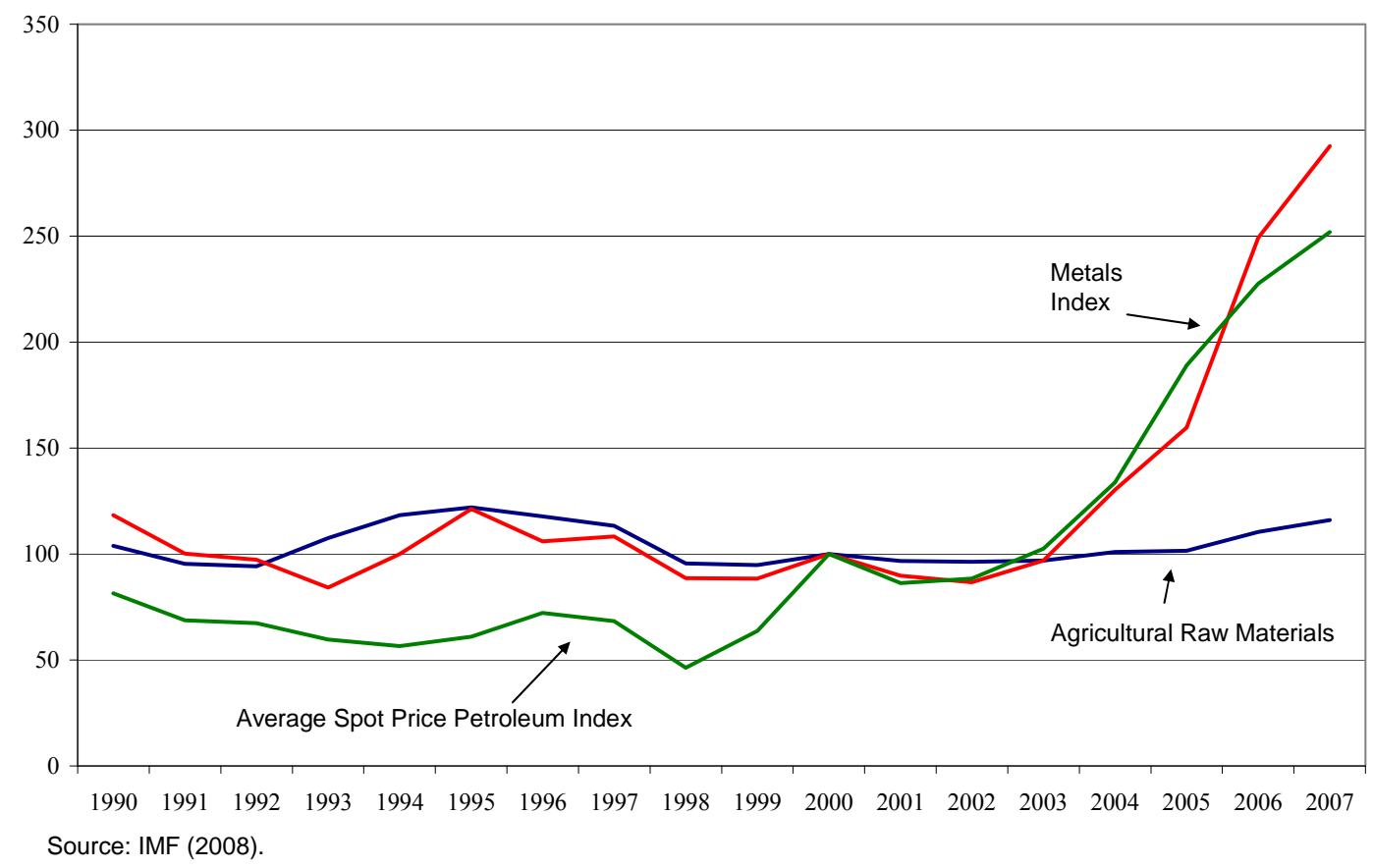

\section{Methodology}

The dependent variable of our probit is a dummy that takes the value $\mathrm{D}=1$ when it meets the criteria defined for each of these three types of episodes. The independent variables are those growth determinants described in the previous section. We also include a constant and the gap between GDP and its potential (calculated using the Hodrick-Prescott filter) to account for any turnaround that is simply a cyclical output correction.

The precise specification of each independent variable depends on whether the variable is an event (conflict, economic liberalization, structural adjustment), time-invariant (British colony, WAEMU/CEMAC, nonfuel primary exporters, fuel exporters, longitude, population close to the coast, ethnic fractionalization), or time-variant (all other variables). Event variables are dummies that take the value of 1 in the year the event occurs and also in the next four years to account for any delay in the impact of the event on growth. Timeinvariants are specified as either (i) the constant value (population close to the sea and ethnic fractionalization) or (ii) a dummy that takes the value of 1 when the definition is met (all other time-invariants). Time-variants are specified in any particular year $t$ as the percent change in the average value of the variable from period $[\mathrm{t}-5, \mathrm{t}]$ to $[\mathrm{t}, \mathrm{t}+5]$. The latter specification mimics one of the definitional criteria used to identify a growth turnaround. 
We run separate probits (Table 2) for growth accelerations, decelerations, and growth collapses ${ }^{19}$. Moving to a general model approach, we compare the policy variables across the three episodes and draw conclusions. The pooled cross-section and time-series nature of the sample requires the use of a random effects probit model, which allows us to obtain unbiased parameter estimates and consistent standard errors in the face of within-unit serial correlation and heteroscedastic standard errors across units (Maddala, 1987). For specification robustness we run probits in which political/institutional variables are not specified as changes but as levels (Appendix Table 2); include growth determinants category by category (Appendix Table 3); and interact political/institutional variables with ethnic fractionalization (Appendix Table 4). We comment on the impact of growth determinants on the likelihood of growth turnarounds only when the statistical significance of their coefficients is above 90 percent. WAEMU/CEMAC and malaria are generally dropped from our probit regressions due to multicollinearity.

\section{ECONOMETRIC ANALYSIS}

\section{External Shocks}

One of the clearest results of our regressions is that improvements in the terms of trade and accelerations in world demand growth increase the probability of growth accelerations, while contractions in the terms of trade are related to collapses. These results are quite robust to changes in specification. The implications for government policies is not straightforward: because West African countries are mostly small producers by international standards, their governments cannot directly control these external factors. However, any government policy that succeeds in fostering the development of higher-value-added production may be helpful as it is the terms of trade of raw goods that have been historically more volatile.

The effect of aid on growth acceleration appears to be insignificant, possibly because aid on its own is not enough for growth - the economic environment matters. We could speculate, for instance, that the positive effect of aid is likely to be cancelled by its impact on rent-seeking and corruption. In contrast, aid is negatively correlated to growth collapses, which could either imply that significant reductions in aid often leads to collapses or that factors that lead to collapses also prompt donors to reduce the amount of aid they provide.

Remittances do not have a statistically significant effect on turnaround periods, suggesting that they do not matter in growth episodes. This is perhaps because remittances are largely used for consumption rather than investment, and therefore they may foster shortterm growth but not sustained growth turnarounds.

\footnotetext{
${ }^{19}$ Appendix Table 1a-c present correlation between growth determinants and the occurrence of growth turnarounds. They highlight the statistical association between terms of trade swings and economic liberalization.
} 


\section{Political and Institutional Factors}

In our main probit regressions (Table 4), both "War Ends" and War Begins" are dropped from the estimation due to multicollinearity, and our correlation tables do not allow for any strong statistical statement about the link between accelerations, decelerations, and conflict. However, a simple correlation analysis between GDP growth and a conflict dummy (which takes the value of 1 in the year of conflicts and 0 otherwise) shows the strong and negative statistical relation between conflict and growth (Appendix Table 5) on a year-toyear basis. It may be that although conflicts do immediately affect economic growth, they may not do so in a sustained enough manner to meet the criteria for growth turnarounds.

The Polity 2 variable, which reflects the level of institutional democracy on a scale ranging from -10 (least democratic) to 10 (most democratic), does not seem to have a statistically significant effect on growth turnarounds. Nevertheless, when this variable is interacted with ethnic fractionalization, Polity 2 does show a positive and statistically significant effect on growth accelerations, and the negative sign of the interaction term (see Appendix Table 4) implies that democracy has a more positive effect in less fractionalized countries.

Periods of stability, measured by the absence of political interruptions, seem to be positively related to growth accelerations, suggesting that political stability matters. It then appears that in Western African countries the benefits of a stable political environment have outweighed the potentially harming effects of the appearance of distributional coalitions during long regimes that could engage in rampant corruption and rent-seeking.

Reductions in corruption have actually decreased the probabilities of moderate deceleration but, interestingly, corruption does not change the likelihood of growth acceleration or collapse. Equally surprising, a fall in the quality of the bureaucracy is positively related to growth acceleration, according to one of the probit specifications. However, this statistical relation is not robust to changes in the specification of the probits. Accountability and Law and Order appear to have a statistically significant effect on some growth turnarounds, but their relations are not robust. In fact, the sign of their coefficient switches under different specifications. Note that being a former British colony, and therefore having British institutions, does not on its own increase the probability of a turnaround.

\section{Economic Reforms}

Macroeconomic stability, as measured by inflation, does not seem to be an important determinant of turnarounds. This could be due to the fact that Western Africa as a region has not suffered the macroeconomic instability of, for instance, Latin American countries.

Rather, economic liberalization has had a positive, significant, and robust impact on the probability of growth acceleration in Western Africa. And even though market-oriented reforms have often been blamed for growth collapses in developing countries, there are no episodes of liberalization followed by collapse. It appears that the economic liberalizations launched in West Africa have made a net positive contribution to their economic recovery after the crises they experienced in the 1980s.

Credit growth is negatively correlated with the likelihood of growth collapses in Western Africa. Given that banking-generated crisis are rare in this region, this result probably reflects the fact that economic collapses lead to financial disintermediation more than the reverse. 
Table 4: Probit Estimation of Growth Accelerations, Decelerations, and Collapses

Probit Estimation of Growth Accelerations, Decelerations and Collapses

\begin{tabular}{|c|c|c|c|}
\hline & Accelerations & Decelerations & Collapses \\
\hline \multicolumn{4}{|l|}{ External shock } \\
\hline Terms of Trade Change & 0.01* & -0.01 & $-0.05 * * *$ \\
\hline Change in Aid-Funded Expenditures & 0.00 & 0.00 & $-0.02 * *$ \\
\hline Change in Remittances & 0.00 & & \\
\hline Change in World Demand Growth & $1.02 *$ & 0.25 & 0.29 \\
\hline \multicolumn{4}{|l|}{ Political and Institutional Factors } \\
\hline \multicolumn{4}{|l|}{ War End } \\
\hline Change in Polity 2 Index & 0.15 & -0.08 & -0.06 \\
\hline Years without political interruption & $0.14 * *$ & $-0.04 *$ & 0.01 \\
\hline Change in Corruption Index & 0.80 & $-0.33^{*}$ & 0.15 \\
\hline Change in Bureaucratic Quality Index & $-1.15^{* *}$ & 0.29 & 0.19 \\
\hline Change in Accountability Index & -0.95 & -0.19 & $-0.50 * * *$ \\
\hline Change in Law and Order & 0.65 & 0.16 & $0.58 * * *$ \\
\hline Former British Colony & -0.41 & -0.90 & 0.01 \\
\hline \multicolumn{4}{|l|}{ Economic Reforms } \\
\hline Inflation Rate & 0.00 & 0.00 & \\
\hline Economic Liberalization & $3.381 * * *$ & -3.84 & \\
\hline Change in Domestic Credit-to-GDP & 0.02 & 0.00 & $-0.01 * *$ \\
\hline Structural Adjustment Program & -1.42 & -7.70 & -7.74 \\
\hline \multicolumn{4}{|l|}{ Other } \\
\hline Output Gap & -8.73 & -2.23 & $10.98 * *$ \\
\hline Rainfall Variation & -13.13 & -1.48 & -0.69 \\
\hline Primary Exporters (nonfuel) & $-2.93^{* *}$ & -0.45 & -0.28 \\
\hline Longitude & $0.09 *$ & $-0.08 * * *$ & 0.02 \\
\hline Population within $100 \mathrm{~km}$ of coast & $7.12 * *$ & -1.34 & $5.36^{* * *}$ \\
\hline Ethnic Fractionalization & 0.02 & -0.01 & 0.02 \\
\hline Constant & -2.8 & 0.51 & $-5.96 * *$ \\
\hline Observations & 111 & 201 & 201 \\
\hline Number of nid & 9 & 13 & 13 \\
\hline Pseudo $\mathrm{R}^{2}$ & 0.54 & 0.23 & 0.36 \\
\hline
\end{tabular}

Standard errors in parentheses

$* * * \mathrm{p}<0.01, * * \mathrm{p}<0.05, * \mathrm{p}<0.1$

\section{Other Factors}

Our probit results do not show a robust relation between rainfall and growth turnarounds. This suggests that although rain may explain growth in one- or two-year periods, it does not have a significant effect in explaining longer-term episodes of acceleration or deceleration.

Geographic location has a significant impact on the likelihood of turnarounds. Countries with more of their population close to the coast have higher chances of growth acceleration. Similarly, a country located at a longitude west of the meridian and therefore closer to the coast has a higher probability of growth acceleration. However, under several specifications our probits also show that having a larger share of the population close to the sea also increases the likelihood of a growth collapse. Thus, it seems that economies with more of their populations close to the coast experience higher output volatility, probably 
because they are more affected by the back-and-forth of the global economy, whereas landlocked economies are usually dominated by highly stable (often stagnant) self-sufficient rural activities.

Ethnic fractionalization on its own does not have a close relationship with growth turnarounds. Only under one specification (see Appendix Table 3c) is higher ethnic fractionalization significantly associated with collapses. This may imply that economic collapses are more likely in the unstable environment characteristic of highly fractionalized societies, but again this result is not robust to changes in specification.

\section{Conclusion And Policy Implications}

The literature has focused on long-term growth in Africa, but given the high volatility of output in this region we think a more discriminating and focused approach is needed. This paper has attempted to explain specific episodes of growth turnarounds. We found that, contrary to the common perception that sustained growth is unattainable in West Africa, growth accelerations have been frequent in the region. However, decelerations have been equally frequent, as have, more worryingly, collapses that led to long-lasting economic contractions, which in several cases erased any economic gains from accelerations.

We also found that growth turnarounds are associated with several determinants commonly cited in the literature. Accelerations were most likely triggered by increases in the terms of trade, rising world growth, and economic liberalization. They happened more often during long-standing regimes and in coastal countries. Decelerations, which are mainly determined by the duration of a political regime, are less likely when corruption is more effectively controlled. Growth collapses are linked to negative terms of trade shocks, declines in foreign aid, worsening accountability, improvements in law and order, and reduction in domestic credit. They are also more frequent in countries that are closer to the sea.

Chart 5: Statistically significant determinants of growth accelerations, decelerations and collapses

\begin{tabular}{|c|c|c|c|c|}
\hline & $\begin{array}{l}\text { External } \\
\text { Shock }\end{array}$ & $\begin{array}{l}\text { Political } \\
\text { Change }\end{array}$ & $\begin{array}{l}\text { Economic } \\
\text { Reform }\end{array}$ & Other \\
\hline Acceleration & $\begin{array}{l}\text {-Terms of Trade (+) } \\
\text {-World Demand (+) }\end{array}$ & $\begin{array}{l}\text {-Duration of Political } \\
\text { Regimes }(+) \\
\text {-Change in quality of } \\
\text { bureaucracy }(-)\end{array}$ & •Economic Reform (+) & $\begin{array}{l}\cdot \text { Primary Exporter (-) } \\
\cdot \text { - Longitude }(+) \\
\cdot \text { Coastal Population }(+)\end{array}$ \\
\hline Deceleration & & $\begin{array}{l}\text {-Duration of Political } \\
\text { Regimes (-) } \\
\text { •Corruption Control (-) }\end{array}$ & & •Longitude (-) \\
\hline $\begin{array}{l}\text { Growth } \\
\text { Collapse }\end{array}$ & $\begin{array}{l}\text {-Terms of Trade(-) } \\
\text {-Aid (-) }\end{array}$ & $\begin{array}{l}\text { - Change in } \\
\text { Accountability (-) } \\
\text {-Change in Law and } \\
\text { Order }(+)\end{array}$ & -Domestic Credit (-) & $\begin{array}{l}\text {-Output gap }(+) \\
\cdot \text { Coastal Population }(+)\end{array}$ \\
\hline
\end{tabular}


These results have interesting implications for policy making. It appears that governments that engage in political stabilization and market-oriented reforms can significantly increase the chances of acceleration. And although the terms of trade are externally determined in the short-to-medium run, long-run policies that promote highervalue-added products could eventually reduce the importance of commodity price volatility in their terms of trade. The evidence presented here may also support the need to strengthen the financial system, avoid policies that fend off foreign aid, and control corruptionalthough we recognize that issues of endogeneity are probably more important for these variables. 


\section{REFERENCES}

Abed, George, and Sanjeev Gupta, 2002, eds. Governance, Corruption, and Economic Performance (Washington: International Monetary Fund).

Acemoglu, Daron, Simon Johnson, and John Robinson, 2001, "The Colonial Origins of Comparative Development: An Empirical Investigation" American Economic Review, Vol. 91, pp. 1369-1401

Aghion, Philippe, Alberto Alesina, and Francesco Trebbi, "Endogenous Political. Institutions," Quarterly Journal of Economics, Vol. 119, pp 565-612

Barro, Robert J., 1991, “Economic Growth in a Cross Section of Countries," Quarterly Journal of Economics, Vol. 56, pp.407-43.

Burnside, Craig, and David Dollar, 2000, "Aid, Policies, and Growth," American Economic Review, Vol. 90, pp. 847-68.

Clemens, Michael, Steven Radelet, and Rikhil Bhavnani, 2004, "Counting Chickens When They Hatch: The Short-Term Effect of Aid on Growth," Center for Global Development Working Paper No. 44 (Washington: Center for Global Development).

Collier, Paul, 2000, "Economic Causes of Civil Conflict and Their Implications for Policy" (World Bank: Washington DC)

Collier, Paul, and Jan-Willem Gunning. 1999 "Explaining African economic performance" Journal of Economic Literature, Vol. 37, pp. 64-111

Collier, Paul and Anke Hoeffler, 1996, "Economic Causes and Consequences of Civil War: A Discussion of the Possible Policy Interventions" 151-158 in Michael Dauderstädt and Arne Schildberg (eds) "Dead Ends of Transition: Rentier Economies and Protectorates, (Frankfurt: Campus)

De Long Bradford and Lawrence Summers, 1991, "Equipment Investment and Economic Growth," Quarterly Journal of Economics, Vol. 106, pp. 445-502

Diamond, Jared, 1997, Guns, Germs, and Steel (New York: W.W. Norton and Co.).

Djankov, Simeon, Rafael La Porta, Florencio Lopez-de-Silanes, and Andrei Shleifer, 2003, "The New Comparative Economics," Journal of Comparative Economics, Vol. 31,pp. 595-619.

Doppelhofer, Gernot, Ronald Miller, and Xavier Sala-i-Martin, 2004, "Determinants of Long-Term Growth: A Bayesian Averaging of Classical Estimates (BACE) Approach," American Economic Review, Vol. 94, pp. 813-35.

Easterly, William, 2003, "Can Foreign Aid Buy Growth?” Journal of Economic Perspectives, Vol. 17, pp. 23-48.

Easterly, William, and Ross Levine, 1998, "Troubles with the Neighbors: Africa's Problem, Africa's Opportunity," Journal of African Economies, Vol. 7, pp. 120-42.

Easterly, William, Michael Kremer, Lant Pritchett and Lawrence Summers, 1993, "Good Policy or Good Luck?: Country Growth Performance and Temporary Shocks," Journal of Monetary Economics, Vol. 32, pp. 459-483

Funke, Norbert, Eleonora Granziera and Patrick Imam, 2008, "Terms of Trade Shocks and Economic Recovery”. IMF Working Paper No.36 (Washington: International Monetary Fund).

Gallup, John Luke, and Jeffrey D. Sachs, 2001, "The Economic Burden of Malaria," American Journal of Tropical Medicine and Hygiene, Vol. 64, pp. 85-96. 
Gapen, Michael, Adolfo Barajas, Ralph Chami, Peter Montiel, Thomas F. Cosimano, and Connel Fullenkamp, 2008, “Macroeconomic Consequences of Remittances," IMF Occasional Paper No. 259 (Washington: International Monetary Fund).

Hall, Robert, and Charles Jones, 1999, "Why Do Some Countries Produce so Much More Output per Worker than Others?” Quarterly Journal of Economics, Vol. 114, pp. 83116.

Hausmann, Ricardo, Lant Pritchett, and Dani Rodrik, 2005, "Growth Accelerations," Journal of Economic Growth, Vol. 10, pp. 303-29.

Huntington, Samuel, 2000, "Foreword: Cultures Count," in Culture Matters-How Values Shape Human Progress, ed. by L Harrison and S. Huntington (New York: Basic Books).

Johnson, Simon, Jonathan Ostry, and Arvind Subramanian, 2007,“Africa’s Growth Prospects: Benchmarking the Constraints,” NBER Working Paper 13120 (Cambridge, Mass.: National Bureau of Economic Research).

Kaufmann, Daniel. and Aart Kraay, 2002, “Growth Without Governance," World Bank Policy Research Working Paper No. 2928 (Washington: International Monetary Fund).

Kaufmann, Daniel, Aart Kraay, and P. Zoido-Lobaton, 1996, "Government Matters," (photocopy; Washington: World Bank).

Maddala, G. S., 1987, “Limited Dependent Variable Models Using Panel Data," Journal of Human Resources, Vol. 22, pp. 307-38.

Malaney, Pia, Andrew Spielman, and Jeffrey Sachs, 2004, "The Malaria Gap," American Journal of Tropical Medicine and Hygiene, Vol. 71, pp. 141-46.

Mozzafar, Shaheen and James Scarrit, 1999, "The Specification of Ethnic Cleavages and Ethnopolitical Groups for the Analysis of Democratic Competition in Contemporary Africa" Nationalism and Ethnic Politics, Vol. 5, pp.82-117.

Myrdal, Gunnar, 1968, Asian Drama: An Inquiry into the Poverty of Nations (London: Penguin Books).

Ndulu, Benno J., Stephen A. O'Connell, Robert H. Bates, Paul Collier, and Charles C. Soludo, eds., 2000, The Political Economy of Economic Growth in Africa, 1960-2000 (Cambridge, UK: Cambridge University Press).

North, Douglas, 1994, Institutions Matter (Cambridge, UK: Cambridge University Press).

Ocampo, Jose-Antonio and Maria Angela Parra, 2003, “The Terms of Trade for Commodities in the Twentieth Century," ECLAC Review, No. 79, pp.7-35

Olson, Mancur, 1982, "The Rise and Decline of Nations: Economic Growth, Stagflation, and

Social Rigidities," Yale University Press: New Haven

Pritchett, Lant, 1998. "Patterns of economic growth : hills, plateaus, mountains, and plains," Policy Research Working Paper Series 1947 (World Bank: Washington DC)

Rodriguez, Francisco. and Dani Rodrik, 1999. "Trade Policy \& Economy Growth: a Skeptic's Guide to the Cross-National Evidence," NBER Working Papers No. 9912

Wallenstein, Peter and Margareta Sollenberg, 1995 "After the Cold War: Emerging Patterns of Armed Conflict, 1989-94” Journal of Peace Research Vol. 32, pp. 345-60

Wacziarg, Romain, and Karen Welch, 2008, "Trade Liberalization and Growth: New Evidence," World Bank Economic Review, Vol. 22, pp. 187-231. 
Appendix Table 1.a

Averages of Growth Determinants in Acceleration and Non-Acceleration Years*

Non-Acceleration Acceleration Years Years

External shock

Terms of Trade Change (annual, \%)

7.991

31.676

Change in Aid-Funded K Expenditures (annual, \%)

52.240

121.389

Change in Remittances (annual, \%)

145.623

42.848

Change in World GDP Growth Rate (\%)

$-0.255$

$-0.218$

Political and Institutional Factors

War End (\%)

3.095

3.608

Change in Polity 2 Index (\%)

7.450

1.440

Years without political interruption

12.731

12.319

Change in Corruption Index (\%)

Change in Bureaucratic Quality Index (\%)

6.140

$-8.610$

Change in Accountability Index (\%)

$-14.448$

$-16.849$

Change in Law and Order (\%)

31.541

23.935

Former British Colony (\%)

8.687

12.380

WEMU Countries (\%)

23.810

18.041

CEMAC Countries (\%)

31.071

31.443

24.167

28.351

Economic Policies

Economic Liberalization (\%)

10.412

30.986

Inflation Rate (annual, \%)

Change in Domestic Credit-to-GDP (annual, \%)

2.323

15.165

Structural Adjustment Program (\%)

1.905

3.093

Other

Rainfall Variation (\%)

0.093

0.091

Non-Fuel Primary Exporters (\%)

50.714

46.907

Fuel Exporters (\%)

13.214

15.464

Longitude (Degrees)

0.311

0.314

Population within $100 \mathrm{~km}$ of coast (\%)

18.571

16.495

Ethnic Fractionalization (\%)

72.695

73.776

* The means of those variables in bold are statistically different, according to their $95 \%$ confidence intervals. 
Appendix Table 1.b

Averages of Growth Determinants in Deceleration and Non-Deceleration Years*

Non-Deceleration Deceleration Years

Years

\section{External shock}

Terms of Trade Change (annual, \%)

12.214

18.340

Change in Aid-Funded K Expenditures (annual, \%)

62.518

74.002

Change in Remittances (annual, \%)

117.625

170.303

Change in World GDP Growth Rate (\%)

$-0.242$

$-0.263$

Political and Institutional Factors

War Beginning (\%)

4.432

n.a.

Change in Polity 2 Index (\%)

8.100

3.880

Years without political interruption

12.225

15.000

Change in Corruption Index (\%)

4.186

$-4.860$

Change in Bureaucratic Quality Index (\%)

$-15.352$

$-6.616$

Change in Accountability Index (\%)

29.794

38.851

Change in Law and Order (\%)

8.727

19.395

Former British Colony (\%)

23.750

16.883

WEMU Countries (\%)

31.136

31.169

CEMAC Countries (\%)

25.341

22.727

\section{Economic Reforms}

Economic Liberalization (\%)

13.753

10.909

Inflation Rate (annual, \%)

9.603

10.238

Change in Domestic Credit-to-GDP (annual, \%)

5.835

3.539

Structural Adjustment Program (\%)

2.386

0.649

\section{Other}

Rainfall Variation (\%)

0.093

0.091

Non-Fuel Primary Exporters (\%)

50.341

48.052

Fuel Exporters (\%)

13.295

15.584

Longitude (Degrees)

$-1.625$

$-2.796$

Population within $100 \mathrm{~km}$ of coast (\%)

37.679

41.302

Ethnic Fractionalization (\%)

73.007

72.202

\footnotetext{
* The means of those variables in bold are statistically different, according to their $95 \%$ confidence intervals
} 
Appendix Table 1.c

Averages of Growth Determinants in Collapse and Non-Collapse Years

Non- Collapse Years

Collapse Years

External shock

Terms of Trade Change (annual, \%)

15.631

$-6.077$

Change in Aid-Funded K Expenditures (annual, \%)

68.829

41.640

Change in Remittances (annual, \%)

77.811

584.285

Change in World GDP Growth Rate (\%)

$-0.290$

0.021

Political and Institutional Factors

War Beginning (\%)

3.661

5.128

Change in Polity 2 Index (\%)

7.038

9.820

Years without political interruption

11.564

24.658

Change in Corruption Index (\%)

1.310

21.733

Change in Bureaucratic Quality Index (\%)

$-17.290$

4.424

Change in Accountability Index (\%)

35.924

$-12.286$

Change in Law and Order (\%)

6.779

28.384

Former British Colony (\%)

21.548

37.179

WEMU Countries $(\%)$

31.695

24.359

CEMAC Countries (\%)

24.372

32.051

Structural Adjustment Program (\%)

2.386

0.649

Economic Reforms

Economic Liberalization (\%)

15.222

n.a.

Inflation Rate (annual, \%)

9.336

13.970

Change in Domestic Credit-to-GDP (annual, \%)

7.631

$-13.363$

Structural Adjustment Program (\%)

2.301

n.a.

Other

Rainfall Variation (\%)

0.094

0.082

Non-Fuel Primary Exporters (\%)

50.105

48.718

Fuel Exporters (\%)

13.389

16.667

Longitude (Degrees)

$-1.887$

$-0.736$

Population within $100 \mathrm{~km}$ of coast (\%)

37.837

42.897

Ethnic Fractionalization (\%)

72.518

77.471

* The means of those variables in bold are statistically different, according to their $95 \%$ confidence intervals. 
Appendix Table 2

Probit Estimation of Growth Accelerations, Decelerations and Collapses: Political Variables Specified in Levels

\begin{tabular}{|c|c|c|c|}
\hline & Accelerations & Decelerations & Collapses \\
\hline \multicolumn{4}{|l|}{ External shock } \\
\hline Terms of Trade Change & $0.01 *$ & 0.005 & $-0.053^{* * *}$ \\
\hline Change in Aid-Funded Expenditures & 0.00 & 0.00 & 0.00021 \\
\hline Change in Remittances & 0.00 & & \\
\hline Change in World Demand Growth & $1.123 * * *$ & 0.017 & 0.331 \\
\hline \multicolumn{4}{|l|}{ Political and Institutional Factors } \\
\hline War End & 15.46 & & \\
\hline Change in Polity 2 Index & $0.454 * *$ & -0.23 & -0.042 \\
\hline Years without political interruption & $0.155^{* *}$ & $-0.070 *$ & 0.016 \\
\hline Corruption Index & 0.89 & $-1.732 * *$ & 0.107 \\
\hline Bureaucratic Quality Index & $-1.143 * *$ & $1.204 * *$ & 0.246 \\
\hline Accountability Index & -0.991 & -0.681 & $-0.580 * * *$ \\
\hline Law and Order & 0.775 & 0.812 & $0.509 * *$ \\
\hline Former British Colony & -0.28 & -2.14 & 0.182 \\
\hline \multicolumn{4}{|l|}{ Economic Reforms } \\
\hline Inflation Rate & 0.00 & 0.00 & \\
\hline Economic Liberalization & $3.374 * * *$ & -3.826 & -7.19 \\
\hline Change in Domestic Credit-to-GDP & 0.0168 & 0.00 & $-0.019 * *$ \\
\hline Structural Adjustment Program & -1.529 & -6.14 & -7.48 \\
\hline \multicolumn{4}{|l|}{ Other } \\
\hline Output Gap & -16.59 & -5.517 & $10.55^{* *}$ \\
\hline Rainfall Variation & -12.69 & $-20.61 *$ & -0.799 \\
\hline Primary Exporters (nonfuel) & $-2.940 * *$ & 0.919 & -0.063 \\
\hline Longitude & 0.104* & $-0.294 * *$ & 0.016 \\
\hline Population within $100 \mathrm{~km}$ of coast & $7.706 * * *$ & $-4.501 *$ & $5.132 * * *$ \\
\hline Ethnic Fractionalization & 0.0298 & 0.0339 & 0.0153 \\
\hline Constant & -4.185 & 0.686 & $-5.422 * *$ \\
\hline Observations & 111 & 126 & 201 \\
\hline Number of nid & 9 & 9 & 13 \\
\hline Pseudo $\mathrm{R}^{2}$ & 0.56 & 0.37 & 0.38 \\
\hline
\end{tabular}

Standard errors in parentheses

$* * * \mathrm{p}<0.01, * * \mathrm{p}<0.05, * \mathrm{p}<0.1$ 


\section{Appendix Table 3a}

Probit Estimation of Growth Accelerations by Category of Independent Variable

\begin{tabular}{|c|c|c|c|c|}
\hline & I & II & III & IV \\
\hline \multicolumn{5}{|l|}{ External shock } \\
\hline Terms of Trade Change & $0.01 *$ & & & \\
\hline Change in Aid-Funded Expenditures & $0.001 *$ & & & \\
\hline Change in Remittances & 0.00 & & & \\
\hline Change in World Demand Growth & $0.155^{*}$ & & & \\
\hline \multicolumn{5}{|l|}{ Political and Institutional Factors } \\
\hline War End & & 0.632 & & \\
\hline Change in Polity 2 Index & & 0.025 & & \\
\hline Years without political interruption & & $0.026 *$ & & \\
\hline Change in Corruption Index & & $-0.02 * * *$ & & \\
\hline Change in Bureaucratic Quality Index & & 0.002 & & \\
\hline Change in Accountability Index & & -0.005 & & \\
\hline Change in Law and Order & & -0.002 & & \\
\hline Former British Colony & & -0.47 & & \\
\hline \multicolumn{5}{|l|}{ Economic Reforms } \\
\hline Inflation Rate & & & -0.011 & \\
\hline Economic Liberalization & & & $0.623 * * *$ & \\
\hline Change in Domestic Credit-to-GDP & & & $0.001 * * *$ & \\
\hline Structural Adjustment Program & & & 0.113 & \\
\hline \multicolumn{5}{|l|}{ Other } \\
\hline Output Gap & -1.044 & $-9.616^{*}$ & $-6.878 * * *$ & $-3.599 * * *$ \\
\hline Rain Volatility & & & & $-3.409 * *$ \\
\hline Primary Exporters (nonfuel) & & & & -0.169 \\
\hline Longitude & & & & -0.001 \\
\hline Population within $100 \mathrm{~km}$ of coast & & & & -0.349 \\
\hline Ethnic Fractionalization & & & & 0.003 \\
\hline Constant & $-0.869 * * *$ & $-1.384 * * *$ & $-0.918 * * *$ & $-0.900 *$ \\
\hline Observations & 258 & 151 & 295 & 721 \\
\hline Number $f$ id & 17 & 14 & 17 & 19 \\
\hline Pseudo $\mathrm{R}^{2}$ & 0.06 & 0.11 & 0.09 & 0.02 \\
\hline
\end{tabular}

Standard errors in parentheses

$* * * \mathrm{p}<0.01, * * \mathrm{p}<0.05, * \mathrm{p}<0.1$ 


\section{Appendix Table 3b}

Probit Estimation of Growth Decelerations by Category of Independent Variable

\begin{tabular}{|c|c|c|c|c|}
\hline & $\mathrm{I}$ & II & III & IV \\
\hline \multicolumn{5}{|l|}{ External shock } \\
\hline Terms of Trade Change & $0.014 * *$ & & & \\
\hline Change in Aid-Funded Expenditures & 0.00 & & & \\
\hline Change in Remittances & 0.00 & & & \\
\hline Change in World Demand Growth & 0.116 & & & \\
\hline \multicolumn{5}{|l|}{ Political change } \\
\hline War End & & -5.879 & & \\
\hline Change in Polity 2 Index & & -0.069 & & \\
\hline Years without political interruption & & -0.002 & & \\
\hline Change in Corruption Index & & 0.004 & & \\
\hline Change in Bureaucratic Quality Index & & -0.004 & & \\
\hline Change in Accountability Index & & $0.007 * *$ & & \\
\hline Change in Law and Order & & 0.004 & & \\
\hline Former British Colony & & 0.23 & & \\
\hline \multicolumn{5}{|l|}{ Economic Reforms } \\
\hline Inflation Rate & & & 0.006 & \\
\hline Economic Reform & & & -0.378 & \\
\hline Change in Domestic Credit-to-GDP & & & -0.001 & \\
\hline Structural Adjustment Program & & & -0.619 & \\
\hline \multicolumn{5}{|l|}{ Other } \\
\hline Output Gap & 4.957 & 8.127 & 3.384 & $3.258 * *$ \\
\hline Rainfall Variation & & & & 0.929 \\
\hline Primary Exporters (nonfuel) & & & & -0.066 \\
\hline Longitude & & & & -0.002 \\
\hline Population within $100 \mathrm{~km}$ of coast & & & & -0.266 \\
\hline Ethnic Fractionalization & & & & -0.003 \\
\hline Constant & $-1.024 * * *$ & $-1.807 * * *$ & $-0.927 * * *$ & $-0.675^{*}$ \\
\hline Observations & 258 & 151 & 295 & 721 \\
\hline Number of nid & 17 & 14 & 17 & 19 \\
\hline Pseudo $\mathrm{R}^{2}$ & 0.06 & 0.13 & 0.03 & 0.01 \\
\hline
\end{tabular}

Standard errors in parentheses

$* * * \mathrm{p}<0.01, * * \mathrm{p}<0.05, * \mathrm{p}<0.1$ 
Appendix Table 3c

Probit Estimation of Growth Collapses Decelerations by Category of Independent Variable

\begin{tabular}{|c|c|c|c|c|}
\hline & I & II & III & IV \\
\hline \multicolumn{5}{|l|}{ External shock } \\
\hline Terms of Trade Change & $-0.031 * * *$ & & & \\
\hline Change in Aid-Funded Expenditures & 0.00 & & & \\
\hline Change in Remittances & $0.001 * *$ & & & \\
\hline Change in World Demand Growth & 0.209 & & & \\
\hline \multicolumn{5}{|l|}{ Political change } \\
\hline War End & & -8.452 & & \\
\hline Change in Polity 2 Index & & 0.041 & & \\
\hline Years without political interruption & & $-0.040 *$ & & \\
\hline Change in Corruption Index & & 0.011 & & \\
\hline Change in Bureaucratic Quality Index & & 0.009 & & \\
\hline Change in Accountability Index & & $-0.011 * *$ & & \\
\hline Change in Law and Order & & 0.013* & & \\
\hline Former British Colony & & -0.39 & & \\
\hline \multicolumn{5}{|l|}{ Economic Reforms } \\
\hline Inflation Rate & & & 0.013 & \\
\hline \multicolumn{5}{|l|}{ Economic Reform } \\
\hline Change in Domestic Credit-to-GDP & & & -0.001 & \\
\hline \multicolumn{5}{|l|}{ Structural Adjustment Program } \\
\hline \multicolumn{5}{|l|}{ Other } \\
\hline Output Gap & $12.79 * *$ & 0.364 & 3.972 & $3.221 * *$ \\
\hline Rainfall Variation & & & & -6.391 \\
\hline Primary Exporters (nonfuel) & & & & 0.134 \\
\hline Longitude & & & & $0.029 *$ \\
\hline Population within $100 \mathrm{~km}$ of coast & & & & $1.797 * *$ \\
\hline Ethnic Fractionalization & & & & $0.031 * *$ \\
\hline Constant & $-2.131 * * *$ & $-1.116 * *$ & $-1.574 * * *$ & $-4.388 * * *$ \\
\hline Observations & 258 & 151 & 295 & 721 \\
\hline Number $f$ id & 17 & 14 & 17 & 19 \\
\hline Pseudo $\mathrm{R}^{2}$ & 0.18 & 0.22 & 0.08 & 0.04 \\
\hline
\end{tabular}

Standard errors in parentheses

$* * * \mathrm{p}<0.01, * * \mathrm{p}<0.05, * \mathrm{p}<0.1$ 
Appendix Table 4

Probit Estimation of Growth Accelerations, Decelerations and Collapses: Political Change Variables Interacted with Ethnic Fractionalization

\begin{tabular}{|c|c|c|c|}
\hline & Accelerations & Decelerations & Collapses \\
\hline \multicolumn{4}{|l|}{ Political and Institutional Factors } \\
\hline Change in Polity 2 Index & $1.662 * *$ & $12.48 * *$ & 0.871 \\
\hline Years without political interruption & $0.030 *$ & -0.04 & $-0.05 * *$ \\
\hline Change in Corruption Index & -0.112 & $-0.647 *$ & -0.005 \\
\hline Change in Bureaucratic Quality Index & 0.051 & $-0.611 *$ & 0.001 \\
\hline Change in Accountability Index & $-0.199 * *$ & $-0.572 * *$ & $0.263^{*}$ \\
\hline Change in Law and Order & 0.044 & 0.17 & -0.028 \\
\hline \multicolumn{4}{|l|}{ Other } \\
\hline Output Gap & -2.62 & -8.80 & 4.282 \\
\hline Ethnic Fractionalization & 0.071 & 0.193 & -0.078 \\
\hline \multicolumn{4}{|c|}{ Interaction of Ethnic Fractionalization with: } \\
\hline Change in Polity 2 Index & $-0.022 * *$ & $-0.173^{* *}$ & -0.014 \\
\hline Change in Corruption Index & 0.001 & $0.009 *$ & 0.001 \\
\hline Change in Bureaucratic Quality Index & -0.001 & 0.008* & 0 \\
\hline Change in Accountability Index & $0.003 * *$ & $0.008 * * *$ & -0.004 \\
\hline Change in Law and Order & -0.001 & -0.002 & 0.001 \\
\hline Constant & $-6.864 * *$ & -16.22 & 4.757 \\
\hline Observations & 141 & 141 & 141 \\
\hline Number of nid & 13 & 13 & 13 \\
\hline Pseudo $\mathrm{R}^{2}$ & 0.16 & 0.45 & 0.38 \\
\hline
\end{tabular}

Standard errors in parentheses

$*_{* *} \mathrm{p}<0.01,{ }^{* *} \mathrm{p}<0.05,{ }^{*} \mathrm{p}<0.1$ 


\section{Appendix Table 5}

GDP Growth in Conflict and Non-Conflict Years

\begin{tabular}{lrrr} 
& Mean & \multicolumn{2}{c}{$95 \%$ Confidence Interval } \\
\hline Non-Conflict Years & 4.096977 & 3.572638 & 4.621316 \\
Conflict Years & -4.034829 & -7.792785 & -0.2768723
\end{tabular}

Source: Armed Conflict Dataset Book (2005) 